\title{
Federal Reserve Transparency and Financial Market Forecasts of Short-Term Interest Rates
}

\author{
Eric T. Swanson \\ Board of Governors of the Federal Reserve System \\ eswanson@frb.gov
}

\begin{abstract}
The 1990s and early 2000s witnessed an unprecedented increase in central bank transparency around the world, yet there has been little empirical work that convincingly demonstrates any economic benefits of increased central bank transparency. This paper shows that, since the late 1980s, U.S. financial markets and private sector forecasters have become: 1) better able to forecast the federal funds rate at horizons out to several months, 2) less surprised by Federal Reserve announcements, 3) more certain of their interest rate forecasts ex ante, as measured by interest rate options, and 4) less diverse in the cross-sectional variety of their interest rate forecasts. We also show that increases in Federal Reserve transparency are likely to have played a role: for example, private sector forecasts of GDP and inflation have not experienced similar improvements over the same period, indicating that the improvement in interest rate forecasts has been special.
\end{abstract}

JEL Classification: E52, E58, E43, E44

Version 1.2

February 9, 2004

I thank Jim Clouse, Vincent Reinhart, Bill Whitesell, and John Driscoll for helpful discussions, comments, and suggestions, and Ryan Michaels for excellent research assistance. The views expressed in this paper, and all errors and omissions, should be regarded as those solely of the author, and do not necessarily represent those of the individuals or groups listed above, the Federal Reserve System, or its Board of Governors. 


\section{Introduction}

The 1990s and early 2000s witnessed an unprecedented increase in central bank transparency, with New Zealand, Canada, the U.K., Sweden, Finland, Israel, Australia, Spain, the European Central Bank, Norway, and several developing countries all adopting an inflation targeting framework for monetary policy, ${ }^{1}$ and many other central banks dramatically increasing the amount of information regularly released to the public. In the U.S., the Federal Reserve began explicitly announcing changes in its federal funds rate target in 1994, began indicating the likely future course of interest rates or "balance of risks" to its economic outlook in 1999, and began releasing individual votes of Committee members in 2002, to name just a few examples (see Table 1 for additional examples). Yet despite the apparent international consensus that increased central bank transparency conveys economic benefits, there is very little empirical work convincingly demonstrating the existence of any such benefits.

One reason for the shortage of conclusive results may be the ambitiousness of previous emprical studies. Demertzis and Hughes Hallett (2002) look for a relationship between central bank transparency and the level or the variability of inflation and output across countries. But cross-country differences in fiscal policies, institutions, and macroeconomic shocks are often large, and the length of time series since the last central bank regime change in most countries is small, particularly for the many countries that adopted inflation targeting in the 1990s. Thus, Bernanke, Laubach, Mishkin, and Posen (1999) note that drawing any conclusions from this type of exercise "is difficult and somewhat speculative" (p. 252); Bernanke et al. nevertheless present evidence that inflation expectations and inflation have come down in inflation-targeting countries, and by more than one would have expected ex ante, but in many cases their "control" countries, such as the U.S. and

\footnotetext{
${ }^{1}$ Inflation targeting is not synonymous with central bank transparency, but in practice countries that adopted inflation targeting in the 1990s at the same time significantly increased the amount of information about monetary policy regularly released to the public.
} 
Australia (prior to the adoption of inflation targeting), also had similar experiences. The above authors' evidence is thus suggestive, but is unlikely to convince many of those who may be skeptical. Indeed, Ball and Sheridan (2003) emphasize macroeconomic performance in control countries as well, and come to exactly the opposite conclusion-that once one allows for mean-reversion in inflation and other macroeconomic time series, there is no evidence that adopting inflation targeting has had any benefits, because countries that adopted inflation targeting were exactly those with above-average inflation prior to adoption.

The present paper asks a less ambitious question and, as a result, obtains much sharper results. The primary effect of an increase in central bank transparency-defined in this paper as the amount of information about the goals and conduct of monetary policy regularly released to the public - should be an increase in financial market and private sector understanding of how the central bank will set policy as a function of the state of the economy. This should lead, ceteris paribus, to an increase in the private sector's ability to forecast the central bank's policy instrument: for example, if the central bank were following a Taylor-type rule, $r_{t}=r^{*}+\pi_{t}+a y_{t}+b\left(\pi_{t}-\pi^{*}\right)$, then an improvement in the private sector's understanding of what values the central bank uses for $r^{*}, a, b$, and $\pi^{*}$ and exactly how the central bank measures the output gap $y_{t}$ would lead to improved private sector forecasts for $r_{t}{ }^{2}$

The present paper investigates to what extent we see such an improvement in financial market and private sector forecasts of short-term interest rates in the U.S. over the past 15 years, given the increases in Federal Reserve transparency that took place over that period (Table 1). In particular, we document: 1) an improvement in financial markets' ability to forecast the federal funds rate, 2) a reduction in financial market surprises around Federal Open Market Committee (FOMC) announcements, 3) a reduction in financial market ex

\footnotetext{
${ }^{2}$ Of course, no central bank follows a policy rule as simple as a Taylor-type rule, but the same reasoning holds for more general mappings from the state of the economy to the policy instrument $r_{t}$. Discussion of a wide variety of Taylor-type rules can be found in Taylor (1999).
} 
ante uncertainty about the future course of short-term interest rates, as measured by interest rate options, and 4) a fall in the cross-sectional dispersion of private sector forecasts of short-term interest rates. Moreover, we show that there have not been similar improvements in private sector forecasts of real GDP and inflation, indicating that private sector forecasts of Federal Reserve policy have improved relative to private sector forecasts of the rest of the economy, strongly suggesting that increases in Federal Reserve transparency have played a role.

A few earlier authors have studied financial market forecasts of short-term interest rates in the 1990s. Poole and Rasche (2000) and Poole, Rasche, and Thornton (2002) note that the frequency of days on which federal funds futures rates changed by a large amount (6 basis points or more) decreased from the pre-1994 to the post-1994 period, and that some case studies of federal funds futures behavior around FOMC meetings also suggest that markets have become better able to anticipate FOMC decisions since February 1994. Lange, Sack, and Whitesell (2003) econometrically document a steady improvement in financial markets' ability to forecast the federal funds rate across three recent subsamples: pre-1989, 1989-1993, and 1994-2000. The present paper updates the sample period of these earlier studies to include data since mid-2000 and finds some of their results to be fragile, due to a dramatic deterioration in financial market forecast accuracy since January 2001. This raises two important questions: First, what are the underlying reasons for the recent forecast deterioration? Second, is the forecast improvement prior to 2001 a robust feature of the data, or does it disappear once we control for factors that explain the deterioration since 2001? In other words, if we blame the recent losses in forecast accuracy on increased volatility in the federal funds rate, then do we also have to attribute the earlier gains in forecast accuracy to reductions in federal funds rate volatility, rather than to increases in Federal Reserve transparency? We bring to bear additional financial market data, such as implied volatility from interest rate options and panel data from private sector forecasts of output, inflation, and interest rates, to help answer these questions. 
The remainder of the paper proceeds as follows. In section 2, we show that financial market forecasts of short-term interest rates have improved throughout the 1990s by all four measures cited earlier, but that there has been a marked reversal of this trend since January 2001. We show in section 3 that this forecast deterioration is well-explained by recent increases in federal funds rate volatility and uncertainty about the U.S. economy; controlling for these factors, we continue to see a very significant downward trend for all four of our financial market forecast measures over the full sample. In section 4, we provide evidence from private sector forecasts of other macroeconomic variables, and from changes in financial market uncertainty around FOMC announcements, that increases in Federal Reserve transparency over this period are likely to have been responsible for at least part of the improvement in interest rate forecasts.

\section{Financial Market Interest Rate Forecast Accuracy}

\section{Federal Funds Futures}

The basic pattern of an improvement in financial markets' ability to forecast shortterm interest rates throughout the 1990s can be seen in Figure 1, which graphs the federal funds futures market's forecast errors from October 1988 through June 2003.

Federal funds futures contracts have traded on the Chicago Board of Trade exchange since October 1988 and settle based on the average federal funds rate that prevails over a given calendar month. ${ }^{3}$ The market is liquid, volumes for the current-month and nearfuture (next one to six months) fed funds futures contracts are high, spreads are narrow, and risk premia are small (Gürkaynak, Sack, and Swanson (2002)). Most importantly, Krueger and Kuttner (1996), Rudebusch (1998), Faust, Swanson, and Wright (forthcoming), and Gürkaynak, Sack, and Swanson (2002) have shown that federal funds futuresbased forecasts pass standard tests of efficiency.

\footnotetext{
${ }^{3}$ The average federal funds rate is calculated as the simple mean of the daily averages published by the Federal Reserve Board, and the federal funds rate on a non-business day is defined to be the rate that prevailed on the preceding business day. See the appendix for details.
} 
The top panel of Figure 1 plots the absolute value of the 1-month-ahead federal funds futures forecast error, defined to be the realized average federal funds rate for a given month minus the fed funds futures forecast made on the last day of the previous month (e.g., the realized average federal funds rate for June minus the market forecast for June as of May 31). The bottom panel plots the absolute value of the 3-month-ahead market forecast error (e.g., the realized funds rate for June minus the market forecast dated March 31).

Both panels of Figure 1 display a clear improvement in the futures market's forecasts of the federal funds rate from 1988 to the end of 2000 (solid lines), which is confirmed by the significantly negative time trends (or negative post-1994 dummies) in the Table to Figure 1. This is essentially the finding documented by Lange, Sack, and Whitesell (2003). What has not been documented previously is that this earlier downward trend has significantly deteriorated or even reversed itself since the beginning of 2001 (dashed lines). This deterioration is readily apparent in Figure 1 and is confirmed by the decrease in magnitude and statistical significance of the downward trends when they are estimated over the full sample (Table to Figure 1). In light of this significant deviation from the earlier trend, the brief rise in market forecast errors that occurred in 1994 and early 1995 begins to take on added significance as well, and previous authors' conclusion that increases in FOMC transparency have led to improved financial market forecasts becomes much more questionable - for example, perhaps it was a decline in federal funds rate volatility, or real GDP or inflation volatility, over the 1990s that was responsible for the improved financial market forecasts over this period, rather than increases in Federal Reserve transparency. We will return to these questions and address them directly in section 3 , below.

\section{Surprise Component of FOMC Announcements}

The general patterns in Figure 1 are representative of those in a wide variety of financial market and private sector forecast accuracy measures. Figure 2 plots the absolute value of the surprise component of FOMC policy announcements, as measured by changes 
in federal funds futures (top panel) and eurodollar futures (bottom panel) around each announcement. Since February 1994, the FOMC has explicitly announced its policy decisions to the public, typically at about $2: 15 \mathrm{pm}$ on the last day of regularly scheduled FOMC meetings. Prior to 1994, FOMC policy decisions were implicitly announced to financial markets through the size and type of open market operation the morning following the FOMC decision. ${ }^{4}$

The top panel of Figure 2 graphs the surprise component of FOMC policy announcements (in absolute value) from October 1988 through June 2003, as measured by changes in the current-month or next-month federal funds futures contract rate around the announcement. These are computed in essentially the same way as in Kuttner (2001); details are provided in the Appendix. Note that, as in Faust, Swanson, and Wright (forthcoming) and Poole, Rasche, and Thornton (2002), we consider surprises generated by FOMC inaction on FOMC dates as well as surprises generated by FOMC actions.

As a second measure of the surprise component of FOMC announcements, the bottom panel graphs changes in the 90-day eurodollar futures rate around each announcement from April 1985 to June 2003. Eurodollar futures contracts settle based on the spot 90day eurodollar rate prevailing on the day of expiration; thus, changes in the eurodollar futures rate mainly reflect revisions to financial markets' outlook for the federal funds rate over a 3-month window beginning on the day of expiration, which we pick to be about 3 months ahead. ${ }^{5}$ The primary advantage of measuring policy expectations farther out the term structure, as in these data, is that market reactions to FOMC announcements

\footnotetext{
${ }^{4}$ Intermeeting policy decisions have typically been announced shortly after the decision both pre- and post-1994; again, these announcements have been explicit rather than implicit since 1994. There are also a few pre-1994 announcements that do not conform to these general timing rules: see Kuttner (2001, 2003), Poole, Rasche, and Thornton (2002), and the Appendix to this paper for details.

5 The 90-day eurodollar rate is the interest rate paid on 90-day interbank time deposits of U.S. dollars in London. Daily quotes are produced by the British Bankers' Association. The 90-day eurodollar rate very closely tracks the expected federal funds rate over the 90-day term of the deposit (Gürkaynak, Sack, and Swanson (2002)). Both spot eurodollars and eurodollar futures are highly liquid, although only the eurodollar futures contracts with expiration in March, June, September, and December are actively traded, so to keep the forecast horizon roughly constant at a 3-month window beginning 3 months ahead, we interpolate between the current- and next-quarter contracts. See the Appendix for details.
} 
will be much less sensitive to the exact timing of monetary policy actions: for example, markets may correctly forecast the size and sign of the next policy move, but be unsure as to whether it will occur at the next FOMC meeting or the meeting after. The federal funds futures surprises in the top panel can be very sensitive to these timing surprises, while the longer-horizon eurodollar futures surprises in the bottom panel will not be - in support of this observation, note that the surprises in the bottom panel are often smaller than those in the top panel, despite the longer forecast horizon. ${ }^{6}$

It is clear from Figure 2 that financial markets were less surprised by FOMC announcements in the late 1990 s than previously, ${ }^{7}$ an observation that is confirmed by the significantly negative time trends (or post-1994 dummies) estimated through the end of 2000 in the accompanying Table to Figure 2. As in Figure 1, however, and as is true in general, this pattern breaks down substantially when we include data after the end of 2000: the estimated time trends and dummy variables decrease in magnitude and lose their statistical significance when estimated over the full sample.

\section{Eurodollar Options}

While financial market forecasts of short-term interest rates in the 1990s were becoming more accurate ex post, market participants were becoming more certain of their forecasts ex ante as well. Figure 3 plots the level of market uncertainty about interest rates from January 1989 through June 2003 derived from six-month-ahead options on 90-day eurodollar deposits. ${ }^{8}$

The top panel plots the implied volatility in basis point terms derived from eurodollar options with six months to expiration, sampled on days before regularly scheduled FOMC

\footnotetext{
${ }^{6}$ Gürkaynak, Sack, and Swanson (2002) show that timing surprises make up a significant fraction of market forecast errors at short (one month or less) horizons.

7 The October 15, 1998 intermeeting ease is the obvious exception to this general rule.

${ }^{8}$ Eurodollar options settle based on the value of the current-quarter 90-day eurodollar futures contract at expiration (which essentially equals the spot 90-day eurodollar rate at expiration). Only the March, June, September, and December options contracts are actively traded, so we interpolate between contracts to maintain a roughly constant six-month-ahead forecast horizon. See the Appendix for details.
} 
meetings. We multiply the implied volatility on the option (where "implied volatility" is the usual measure that assumes a lognormal distribution for the underlying rate) by the expected 90-day eurodollar rate in order to express the implied volatility in basis point terms rather than in $\operatorname{logs}^{9}$ - the problem with implied volatility measured in logs is that it effectively divides uncertainty about the interest rate by the expected level of the interest rate, and the level of the expected 90-day eurodollar rate has been at all-time lows recently; thus, the recent surge in implied volatility (measured in logs) might simply reflect the recent fall in the level of interest rates rather than any increase in market uncertainty (measured in basis points) about the eurodollar rate itself. The recent upswing in uncertainty that is evident in Figure 3 is immune to this criticism, and clearly depicts an increase in market uncertainty about the eurodollar rate itself, measured in basis points.

To ensure that the trends in the top panel are not an artifact of the lognormal distributional assumption, the bottom panel of Figure 3 plots a simple measure of market uncertainty for a more flexible functional form for the probability distribution on the underlying eurodollar rate. This requires using multiple eurodollar options, each with the same expiration date but a different strike rate. ${ }^{10}$ The difference between the 75 th and 25th percentiles of the implied distribution for the underlying eurodollar rate is then plotted. As can be seen in the figure, the overall patterns in financial market uncertainty are not sensitive to the lognormal distributional assumption.

Financial markets' ex ante uncertainty about the eurodollar rate has trended downward very strongly since 1989, as is evident in Figure 3 and as confirmed by the significant negative time trend and post-1994 dummy variables in the accompanying Table to Figure 3. As in earlier figures, this downward trend has deteriorated since the end of 2000,

\footnotetext{
${ }^{9}$ The expected value of the 90-day eurodollar rate at expiration is estimated using the corresponding eurodollar futures contract. The implied volatility of the option is calculated by assuming a lognormal distribution for the underlying eurodollar rate at expiration and backing out the variance of the log eurodollar rate from the price of the option. We use the closest to at-the-money option (which is typically the most liquid) in the top panel of Figure 3. See the Appendix for details.

${ }^{10}$ For simplicity, we assume a step density function with steps centered on the available strike rates.
} 
and exhibits, in addition, a very pronounced upswing in 1994 and early 1995.

\section{Cross-Sectional Dispersion of Private Sector Forecasts}

Finally, just as financial markets were becoming more certain of their short-term interest rate forecasts ex ante, their forecasts were converging toward greater unanimity as well. Figure 4 graphs the the cross-sectional dispersion of individual private sector forecasters' predictions for the 3-month Treasury bill rate, as published in the monthly Blue Chip Consensus survey of forecasters from June 1991 through June 2003.

The top panel plots the difference between the 90th and 10th percentile forecasts of the level of the Treasury bill rate one quarter ahead, and the bottom panel plots the same difference for forecasts of the Treasury bill rate one year ahead. The same trends that were evident in earlier figures are evident in Figure 4 and the Table to Figure 4: namely, a generally declining level of cross-sectional dispersion over the 1990s, with an upswing in 1994 and a more significant rise since January 2001.

\section{Post-2001 Deterioration in Financial Market Forecasts}

It is clear from Figures 1 through 4 that financial market and private sector forecasts of short-term interest rates improved substantially throughout the 1990s, and equally clear that they have lost a significant part of this gain since January 2001. This raises two important questions: First, what are the underlying reasons for the recent forecast deterioration? Second, is the forecast improvement prior to 2001 a robust feature of the data, or does it disappear once we control for factors that explain the forecast deterioration since 2001? In other words, if we blame the recent losses in forecast accuracy on increased volatility in the federal funds rate, then do we also have to attribute the earlier gains in forecast accuracy to reductions in federal funds rate volatility, rather than to increases in Federal Reserve transparency? We now turn our attention to these very important questions. 
January 2001 marked a turning point for the U.S. economy in two key respects. First, on January 3, 2001, the Federal Reserve made the first of what was to become a long sequence of significant cuts in the federal funds rate, and a moving federal funds rate target is presumably much more difficult to forecast than is a stable one. Second, January 2001 roughly coincides with a significant increase in uncertainty about the state of the U.S. economy, particularly the future prospects for U.S. output and employment; thus, the recent deterioration in private sector forecasts of interest rates might simply reflect a deterioration in the ability of the private sector to forecast the U.S. economy as a whole.

Casual observation of the preceding figures lends some support to each of these hypotheses. For example, earlier periods of rapidly changing monetary policy, such as the tightening cycle by the Fed in 1994-5 and the easing cycle in 1991-2, also correspond to periods of unusually poor private sector forecast accuracy. Similarly, the 1990-1 recession in the U.S. and slow recovery afterward correspond to a period of relatively high levels of uncertainty about the future course of the U.S. economy as a whole.

To investigate whether rapid changes in the federal funds rate can help explain the pattern of financial market forecast errors and uncertainty seen in the data, we need a measure of recent federal funds rate volatility or "momentum." Figure 5 graphs the FOMC's target for the federal funds rate from January 1985 through May 2003 (top panel) and a measure of federal funds rate momentum (bottom panel) defined as the absolute value of the difference between the federal funds rate target the day before an FOMC meeting and the value of the target 90 days prior to that meeting. The momentum variable can thus be used to investigate whether a federal funds rate target that has moved substantially in the recent past is also more difficult to forecast going forward. In the bottom panel of Figure 2, we can see that federal funds rate momentum shows noticeable increases in 2001-2, 1994-5, and 1991-2, as well as being higher on average prior to 1990.

To investigate whether uncertainty about the macroeconomy affects interest rate forecast accuracy, we use the cross-sectional dispersion of private sector forecasters' projections 
for real GDP growth and inflation, depicted in Figure 6. For each month from June 1991 through May 2003, the figure plots the difference between the 90th and 10th percentile one-quarter-ahead forecasts for real GDP growth (top panel) and GDP deflator inflation (bottom panel) in the Blue Chip Consensus survey of forecasters. ${ }^{11}$ Some prominent features of these data are a noticeably higher level of macroeconomic uncertainty during the recessions and early recoveries in 1991-2 and 2001-2, a rise in uncertainty about inflation in 1995, and a pronounced spike in uncertainty in 1999Q4 about output growth the following quarter, probably due to some forecasters' concerns about the possible economic effects of the year 2000 date change.

We regress our four measures of interest rate forecast accuracy from the preceding section on the federal funds rate momentum and macroeconomic uncertainty measures described above. In general, we expect estimated coefficients on these variables to be positive, since increases in these variables should tend to raise financial market forecast errors and uncertainty about interest rates. We also include a time trend or post-1994 dummy variable in the regressions to see whether the earlier improvements in private sector forecast accuracy through December 2000 noted in the preceding section remain once we control for these other factors. Results from these regressions are reported in Table 5. ${ }^{12}$ The regressions are all estimated over the full sample through June 2003, since the post-2001 deterioration in forecast accuracy is a primary feature of the data we are trying to understand.

The results in Table 5 strongly support the hypothesis that high federal funds rate momentum leads to a deterioration in financial market forecast accuracy, and increases in

\footnotetext{
${ }^{11}$ We have also experimented with using the 90-10 percentile difference in forecasts one year ahead, and with realized private sector forecast errors for output growth and inflation from the Blue Chip survey (the latter are depicted in Figure 7 and analyzed below). The one-quarter-ahead dispersion of forecasts seemed to perform better as explanatory variables than did either of these other measures, so results are only reported for the one-quarter-ahead dispersion measures for simplicity.

${ }^{12}$ Due to space limitations, only results for regressions including a time trend are reported; results for regressions including the post-1994 dummy variable are qualitatively very similar.
} 
financial market ex ante uncertainty. The coefficients on the momentum variable are in all cases positive and very highly statistically significant, indicating that a federal funds rate that has moved substantially in the recent past is also more difficult to forecast going forward. According to the coefficient estimates in Table 5, roughly 60-70bp out of the 80110bp spikes in fed funds futures forecast errors in Figure 1(b), 40-45bp of the 40-60bp rise in implied volatility in Figure 3(b), and 30-45bp of the 50-100bp rise in cross-sectional dispersion of forecasts in Figure 4(a) can be explained as resulting from the post-2001 rise in federal funds rate momentum.

Our two measures of macroeconomic uncertainty perform much less well as explanatory variables. Although one measure or the other enters significantly in many of the regressions, it is GDP forecast dispersion that enters significantly in some cases and inflation forecast dispersion that enters significantly in others, and it is not obvious why the preferred measure should flip back and forth. Moreover, in many cases, one measure of macroeconomic uncertainty or the other enters with a negative coefficient, which is difficult to interpret since greater uncertainty about either variable should be expected to increase the private sector's interest rate forecast errors and uncertainty. Finally, the sharp upward spike in interest rate forecast errors and uncertainty in January-February 2001 that can be seen in Figures 1 through 4 suggests a more prominent role for federal funds rate momentum than macroeconomic uncertainty in explaining movements in financial market forecast accuracy: while macroeconomic uncertainty increased in 2001 and 2002, it does not have the sudden upward spike in January-February 2001 that both federal funds rate momentum and interest rate forecast errors and uncertainty possess. ${ }^{13}$

The final - and perhaps most important - observation to take away from Table 5 is the robustness of the underlying time trend observed in the preceding section to the inclusion

\footnotetext{
13 Nonetheless, macroeconomic uncertainty does possess some marginal explanatory power beyond federal funds rate momentum, in the sense that when all three variables are included in the regression simultaneously, the hypothesis that the macroeconomic uncertainty variables do not enter can be rejected in almost every case. Thus, macroeconomic uncertainty does appear to play a contributing, albeit secondary, role in explaining the broad patterns we see in the financial market interest rate forecast data.
} 
of these other explanatory variables in the regressions. Even when all of our interest rate momentum and macroeconomic uncertainty measures are included, the time trend is always negative and almost always highly statistically signficant. Moreover, these regressions are all estimated over the full sample through June 2003, over which the time trend by itself was in many cases not statistically significant in the preceding section. To be sure, the estimated downward trends in Table 5 are less steep (by about one third) than those estimated earlier, without any controls, through 2000; thus, controlling for momentum and macroeconomic uncertainty does qualify, at least quantitatively, the trend improvements in financial market forecast accuracy we estimated earlier. But the overall existence of the downward trend seems to be a robust feature of the data that is not overturned by the recent deterioration in financial market forecasts and cannot be explained by a simple secular decline in federal funds rate volatility or macroeconomic uncertainty over the sample.

\section{Explanations for the Downward Trend}

While a trend improvement in financial market forecasts of short-term interest rates appears to be robust feature of the data, the underlying causes of this trend are not immediately clear. One possibility, of course, is that increases in Federal Reserve transparency over the period improved financial markets' ability to forecast the future course of monetary policy - this explanation is offered, for example, by Lange, Sack, and Whitesell (2003) and Poole, Rasche, and Thornton (2002), to explain their empirical findings of better financial market forecasts. A compelling alternative explanation, however, is that there have been significant improvements in the private sector's ability to forecast macroeconomic times series in general: for example, there could have been significant improvements in the private sector's forecasting technology over this period (through improvements in econometric methodology and increases in computing power), or alternatively, forecasters 
could simply have benefitted from "good luck," to the extent that the size and frequency of shocks buffetting the U.S. economy may have fallen over the period covered by our data.

To distinguish between these competing explanations, we compare the behavior of private sector forecasts of interest rates over our sample to the behavior of private sector forecasts of other macroeconomic variables: in particular, GDP and inflation. Figure 6 presented cross-sectional dispersion of private sector forecasts of real GDP growth and inflation, and Figure 7 graphs the private sector's ex post realized forecast errors for these variables over the same period, defined as the difference between the ex post realized value of real GDP growth (top panel) or GDP deflator inflation (bottom panel) for a given quarter minus the one-quarter-ahead Blue Chip Consensus forecast made the previous quarter. Note that, in contrast to the cross-sectional dispersion series in Figure 6, the series in Figure 7 exhibit gaps around the dates of NIPA benchmark revisions (December 1991, January 1996, and October 1999), because revisions to GDP growth rates on these datesresulting from, e.g., switching to chain-weighting and reclassifying business and government software purchases as investment - may increase forecast errors simply because private sector forecasters failed to predict the definition of GDP rather than the underlying state of the economy. We thus omit forecast errors that would be affected by these benchmark revisions from our analysis. ${ }^{14}$

It is immediately clear from Figures 6 and 7 that private sector forecasts of real GDP growth and inflation have not experienced the same degree of improvement as forecasts of short-term interest rates. There is little evidence of a downward trend in any of the figures, either before 2001 or over the full sample. Although not shown due to space constraints, there is similarly very little evidence of a downward trend in cross-sectional dispersion for four-quarter-ahead macroeconomic forecasts or for four-quarter-ahead macroeconomic forecast errors. ${ }^{15}$

\footnotetext{
${ }^{14}$ Including observations from around these benchmark revision dates does not significantly affect any of our results below.

${ }^{15}$ We have also verified that the Blue Chip Consensus forecast errors for short-term interest rates display
} 
Table 6 verifies these observations econometrically. Each of the cross-sectional dispersion and forecast error series in Figures 6 and 7 are regressed on a constant and time trend for the sample through December 2000. ${ }^{16}$ While there is some improvement in private sector forecasts of inflation over this period, as evidenced by downward trends in the cross-sectional dispersion of inflation forecasts at the one- and four-quarter-ahead horizons, and in inflation forecast errors at the one-quarter-ahead horizon, the private sector's forecasts of GDP growth have, if anything, worsened over the same period.

In contrast, private sector forecasts of short-term interest rates over this period have improved remarkably, both in absolute terms and relative to the forecasts of GDP growth and inflation. The estimated downward trends for the interest rate forecast errors and cross-sectional dispersion in Table 6 are both greater in magnitude and much more statistically significant than are those for the forecasts of real GDP growth and inflation. The implication is that improvements in forecasting technology and "good luck" have only marginally benefitted private sector forecasters with respect to their GDP and inflation forecasts over the past 15 years. By contrast, private sector forecasts of short-term interest rates have improved dramatically, strongly suggesting that increases in Federal Reserve transparency have played a role.

Additional evidence that increases in Federal Reserve transparency have been partly responsible for the improvement in financial market forecasts is presented in Figure 8. Here we consider again market uncertainty about interest rates, as measured by implied volatility in basis point terms from eurodollar options (the same series underlying Figure 3), but Figure 8 takes a slightly different perspective, plotting the change in financial market uncertainty from the day before to the day after each regularly scheduled FOMC announcement from January 1989 through June 2003. Thus, the figure depicts whether

the same trend and overall patterns as the federal funds futures market forecast errors in Figure 1. Both series behave qualitatively very similarly. For this reason, and to conserve space, we also do not graph the Blue Chip forecast errors for short-term interest rates.

${ }^{16}$ Results for the full sample period, through 2003:6, are qualitatively very similar. 
and by how much FOMC announcements reduced (or increased) market uncertainty about the future course of interest rates at a horizon of about 6 to 9 months. There is nothing that requires this market uncertainty to fall in response to FOMC announcements, but over most of our sample this has typically been the case - the mean of the series is negative and a large majority of the observations are also negative.

The most striking feature of Figure 8, however, is the clear break in the series in February 1994, when the Federal Reserve began explicitly announcing and explaining changes in its target for the federal funds rate. A Chow test for a break on this date has a $t$-statistic of about 3.5, with an associated $p$-value less than .001 (see the accompanying Table to Figure 8). Indeed, prior to 1994, the change in financial market uncertainty around FOMC announcements is not significantly different from zero; it is only after 1994, when the Fed began explaining its policy actions, that we see significant falls in financial market uncertainty in response to FOMC decisions. ${ }^{17}$

Figure 8 suggests that the Federal Reserve's shift to explicit monetary policy announcements has significantly reduced financial markets' uncertainty about the future course of short-term interest rates, not only for the overnight rate in the immediate future, but even for the level of short-term interest rates at horizons as far ahead as 6 or 9 months.

\section{Conclusions}

Private sector forecasts of short-term interest rates in the U.S. have shown dramatic improvements over the past 15 years, as evidenced by: 1) a reduction in federal funds rate forecast errors at horizons out to several months, 2) a fall in financial market surprises in response to FOMC announcements, 3) a reduction in financial market ex ante uncertainty about the future course of interest rates, derived from interest rate options, and 4) a fall

\footnotetext{
${ }^{17}$ Our results in the graph carefully take into account the exact timing of when FOMC decisions became known to the markets - in particular, recall that FOMC announcements prior to 1994 implicitly took place through the size and type of the next open market operation following the FOMC's decision.
} 
in the cross-sectional dispersion of private sector forecasts of short-term interest rates. Despite a recent upswing in private sector forecast errors and uncertainty since January 2001, an overall downward trend appears to be a robust feature of the data that remains even after controlling for changes in federal funds rate "momentum" and uncertainty about the state of the U.S. economy that took place over the period.

The underlying causes of the downward trend cannot be determined with certainty, but two pieces of evidence strongly suggest that increases in Federal Reserve transparency have played a role. First, market forecast errors and cross-sectional forecast dispersion for interest rates have fallen substantially, while those for GDP and inflation generally have not, indicating an improvement in the private sector's ability to forecast interest rates above and beyond any improvements in forecasting other macroeconomic variables. Second, market uncertainty about the future course of interest rates even 6 to 9 months ahead typically falls substantially after explicit policy announcements and accompanying explanatory statements by the Federal Reserve - which have been made since February 1994 - but shows no significant response to the implicit, unexplained policy announcements that were made by the Fed prior to that date. Although most of the improvement in financial markets' ability to forecast interest rates over the 1990 s appears to have been gradual rather than directly linked to February 1994, it seems reasonable to infer from the above observations that other changes in FOMC transparency, such as those listed in Table 1, have also contributed to the widespread improvement in financial market and private sector forecasts of short-term interest rates that took place over this period. 


\section{Appendix}

\section{Dating of FOMC Announcements}

Our dating of FOMC announcements follows Kuttner (2001) and Poole, Rasche, and Thornton (2000) in all respects except as noted below.

Beginning with the February 1994 FOMC meeting, policy announcements on scheduled FOMC meeting dates are assumed to have taken place at $2: 15 \mathrm{pm}$ the last day of the FOMC meeting. Prior to 1994, FOMC decisions regarding the federal funds rate are assumed to have been implicitly announced the following morning through the size and type of open market operation.

There are a few exceptions to these dating conventions. The intermeeting policy move on October 15, 1998 was announced at 3:15pm, after the close of federal funds futures, eurodollar futures, and eurodollar options markets. The 25bp easing at the November 13, 1990 FOMC meeting was followed by a very volatile federal funds market the following two days; thus, the "Credit Markets" column of The Wall Street Journal did not recognize the policy action until two days later than usual, on November $16 .{ }^{18}$ The $25 \mathrm{bp}$ easing on October 18, 1989, was actually perceived by markets to have taken place on October 16-before the actual FOMC decision - as the Desk decided (in consultation with the Chairman) not to offset excess reserves in the market due to stock market turmoil, the SF earthquake, and anticipation of the FOMC's action two days later (see Kuttner (2003)).

In general, the exact dating of other intermeeting policy moves prior to 1990 is somewhat ambiguous, with alternative series published by the Federal Reserve Bank of New York and unofficially by the FOMC Secretariat's office. We use the timing of announcements as published by the FRBNY, since we have typically found this to correspond to the date on which the policy action became known to the markets, but we drop changes in the FRBNY federal funds rate target series that do not appear in the Secretariat's listing of policy changes, since these are typically small (6.25bp) and were presumably minor technical adjustments in the Desk's day-to-day targeting operations.

See Kuttner (2001, 2003) and Poole, Rasche, and Thornton (2002) for additional details and a listing of dates.

\section{Federal Funds Futures}

Federal funds futures contracts settle based on the average federal funds rate realized over a given calendar month (the contract month). In order to convert this monthly expectation to a forecast for the outcome of the next FOMC meeting, we must assume that market participants assign zero probability to a policy change occurring on any date other than the FOMC meeting date. This assumption is standard in the literature, but to the extent that it is not warranted in a few instances, our forecasts for the outcome of the FOMC meeting will be measured with error. We also make an adjustment for deviations of the federal funds rate from the target rate prevailing on the date of the ex ante forecast

\footnotetext{
${ }^{18}$ We thank Ken Kuttner for providing us with an unpublished detailed chronology of market knowledge of FOMC actions derived from reading the "Credit Markets" column in the WSJ and biweekly market summaries by the Desk around the time of FOMC meetings and intermeeting moves (Kuttner, 2003).
} 
up through the date of the FOMC meeting, since these deviations would be priced into the federal funds futures contract ex post, but would not be forecast errors associated with the outcome of the meeting, because they are confined entirely to the intervening period.

Like Kuttner (2001), we use the same-month federal funds futures contract for each FOMC meeting to calculate the implied forecast for the outcome of the meeting (Poole and Rasche (2000) and Poole, Rasche, and Thornton (2002) use the next-month contract). Like Kuttner, we scale up the surprise in the same-month contract (i.e., the ex post value of the contract minus the ex ante value) by the number of days in the calendar month divided by the number of days remaining after the FOMC meeting, in order to yield the implied surprise in the outcome of the meeting. For late-month meetings (those that occur in the last six days of the month), we use the next-month federal funds futures contract. See Kuttner (2001) for additional description and details.

\section{Eurodollar Futures}

Eurodollar futures contracts have traded on the Chicago Mercantile Exchange since 1984 and settle based on the spot 90-day LIBOR rate quoted by banks on the day of settlement. They are currently the most actively traded futures contracts in the world. Only the March, June, September, and December eurodollar futures contracts are actively traded, however. Since FOMC meetings occur at various points throughout the quarter, using the next maturing eurodollar contract would introduce variation in the horizon of the forecast, from as little as a few days to settlement, to as much as 3 months. As in Faust, Rogers, Swanson, and Wright (2003), we interpolate between adjacent eurodollar futures contracts to maintain a constant horizon of about 3 months after each FOMC meeting. Thus, if the FOMC meeting occurs on the $x$ th day of the quarter, then we put a weight of $(91-x) / 91$ on the eurodollar futures contract that settles at the end of the quarter containing the FOMC meeting, and a weight of $x / 91$ on the eurodollar futures contract that matures at the end of the following quarter. The resulting measure approximates market expectations for a 90-day rate 90 days ahead, which corresponds to the expected federal funds rate from day $t+90$ to day $t+180$, where $t$ denotes the date of the FOMC meeting. See Gürkaynak, Sack, and Swanson (2002) for additional description and details.

\section{Eurodollar Options}

Eurodollar options have traded on the Chicago Mercantile Exchange since January 1989. A eurodollar call option with strike rate $r$ and expiration date $d$ gives the holder the option of making a 90-day eurodollar deposit on date $d$ at the interest rate $r$. Using eurodollar futures data, we can estimate the expected value of the 90-day eurodollar rate on the expiration date $d$ of the options contract. We then assume that the 90-day eurodollar rate on date $d$ is a lognormally-distributed random variable, and use the price of the option to back out the implied volatility of this random variable. Because standardized eurodollar futures and options contracts have expiration dates only near the end of each quarter, we interpolate between the prices of adjacent eurodollar futures contracts, and adjacent eurodollar options contracts, to obtain estimates of a constant-horizon (in this case, six-month-ahead) expected 90-day eurodollar rate and implied volatility for this rate. 
A problem with the usual measure of implied volatility, however, is that it is a dimensionless quantity that represents the standard deviation of the $l o g$ of the variable of interest - i.e., if the random variable $X$ is lognormally distributed, with $\log X$ having mean $\mu$ and variance $\sigma^{2}$, then the "implied volatility" of $X$ is $\sigma$. Since the level of the expected 90-day eurodollar rate has been at all-time lows recently, the recent surge in implied volatility $\sigma$ may simply reflect the fall in the level of interest rates, rather than any increase in market uncertainty about the eurodollar rate itself.

A more useful measure of uncertainty about interest rates is thus the implied standard deviation of the 90-day eurodollar rate (also called the "implied volatility in basis point terms"), which multiplies the usual implied volatility $\sigma$ by the expected value $E[X]$ of the 90-day eurodollar rate. Although technically the standard deviation of $X$ is $\left(e^{\sigma^{2}}-1\right)^{1 / 2} E[X]$ rather than $\sigma E[X]$, these two measures are so close as to be visually indistinguishable in Figure 3. 


\section{References}

Ball, Laurence and Niamh Sheridan. "Does Inflation Targeting Make a Difference?" in Bernanke, Ben (ed.), Inflation Targeting (Chicago: University of Chicago Press, 2003).

Bernanke, Ben, Thomas Laubach, Frederic Mishkin, and Adam Posen. Inflation Targeting: Lessons from the International Experience (Princeton: Princeton University Press, 1999).

Demertzis, Maria and Andrew Hughes Hallett. "Central Bank Transparency in Theory and Practice," Center for Economic Policy Research Discussion Paper 3639, (2002).

Faust, Jon, John Rogers, Eric Swanson, and Jonathan Wright. "Identifying the Effects of Monetary Policy Shocks on Exchange Rates Using High-Frequency Data," Journal of the European Economic Association 1 (2003), pp. 1031-57.

Faust, Jon, Eric Swanson, and Jonathan Wright. "Identifying VARs Based on High-Frequency Futures Data," Journal of Monetary Economics (forthcoming).

Greenspan, Alan. "Transparency in Monetary Policy," speech to the Federal Reserve Bank of St. Louis Economic Policy Conference, October 11, 2001. Text available at the Federal Reserve Board web site.

Gürkaynak, Refet, Brian Sack, and Eric Swanson. "Market-Based Measures of Monetary Policy Expectations," Federal Reserve Board Finance and Economics Discussion Series 02-40 (2002).

Kuttner, Kenneth. "Monetary Policy Surprises and Interest Rates: Evidence from Fed Funds Futures," Journal of Monetary Economics (2001), 523-44.

Kuttner, Kenneth. "Dating Changes in the Federal Funds Rate, 1989-92" unpublished manuscript, Oberlin College (2003).

Lange, Joe, Brian Sack, and William Whitesell. "Anticipations of Monetary Policy in Financial Markets," Journal of Money, Credit, and Banking, forthcoming (2003).

Poole, William and Robert H. Rasche. "Perfecting the Market's Knowledge of Monetary Policy," Journal of Financial Services Research (2000), 255-98.

Poole, William, Robert Rasche, and Daniel Thornton. "Market Anticipations of Monetary Policy Actions," Federal Reserve Bank of St. Louis Economic Review, July/Aug (2002), $65-94$.

TAYlor, John (ed.). Monetary Policy Rules. (Chicago: University of Chicago Press, 1999). 
Table 1: Selected Changes in FOMC Transparency, 1990-2003

Date $\quad$ FOMC Transparency Change

1992-2000 Gradual shift of policy actions to regularly scheduled meeting dates

Mar 1993 Begins releasing minutes of FOMC meetings (with 6-8 week lag)

Nov 1993 Begins releasing transcripts of FOMC meetings (with 5 year lag)

Feb 1994 Begins explicitly announcing changes in federal funds rate target

1994-2003 Gradual shift to longer, more descriptive press releases after FOMC decisions

May 1999 Begins releasing statement about economic outlook even after no change in federal funds rate target

May 1999 Begins announcing policy "tilt" indicating most likely future interest rate action

Jan 2000 Replaces "tilt" with statement describing "balance of risks" to economic outlook

Oct 2001 Chairman Greenspan delivers a speech describing FOMC's moves toward greater transparency

Mar 2002 Begins releasing votes of individual Committee members and preferred policy choice of any dissenters 


\section{Figure 1: Federal Funds Futures Market Forecast Errors}

(a) 1-month-ahead Forecast Errors for Federal Funds Rate

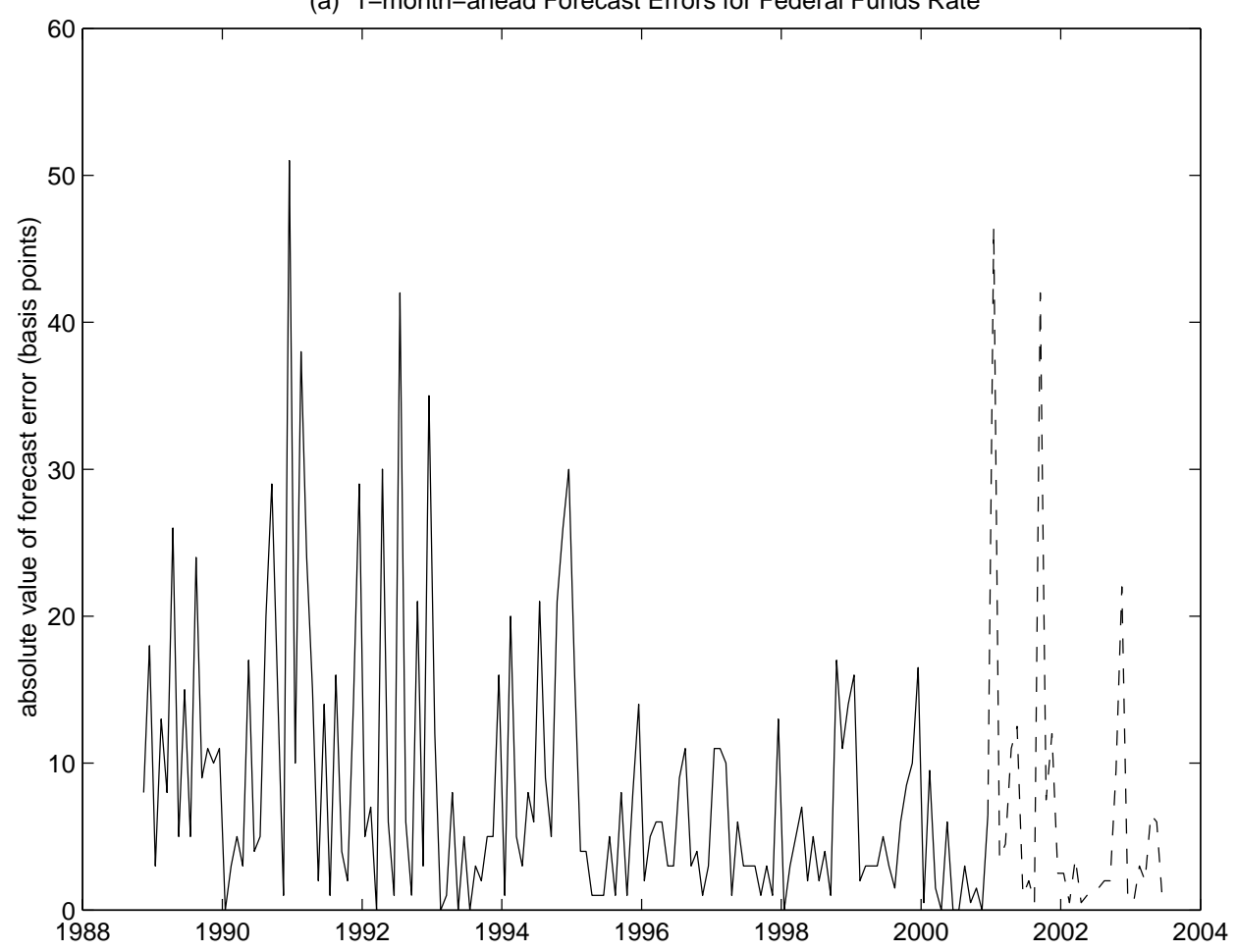

(b) 3-month-ahead Forecast Errors for Federal Funds Rate

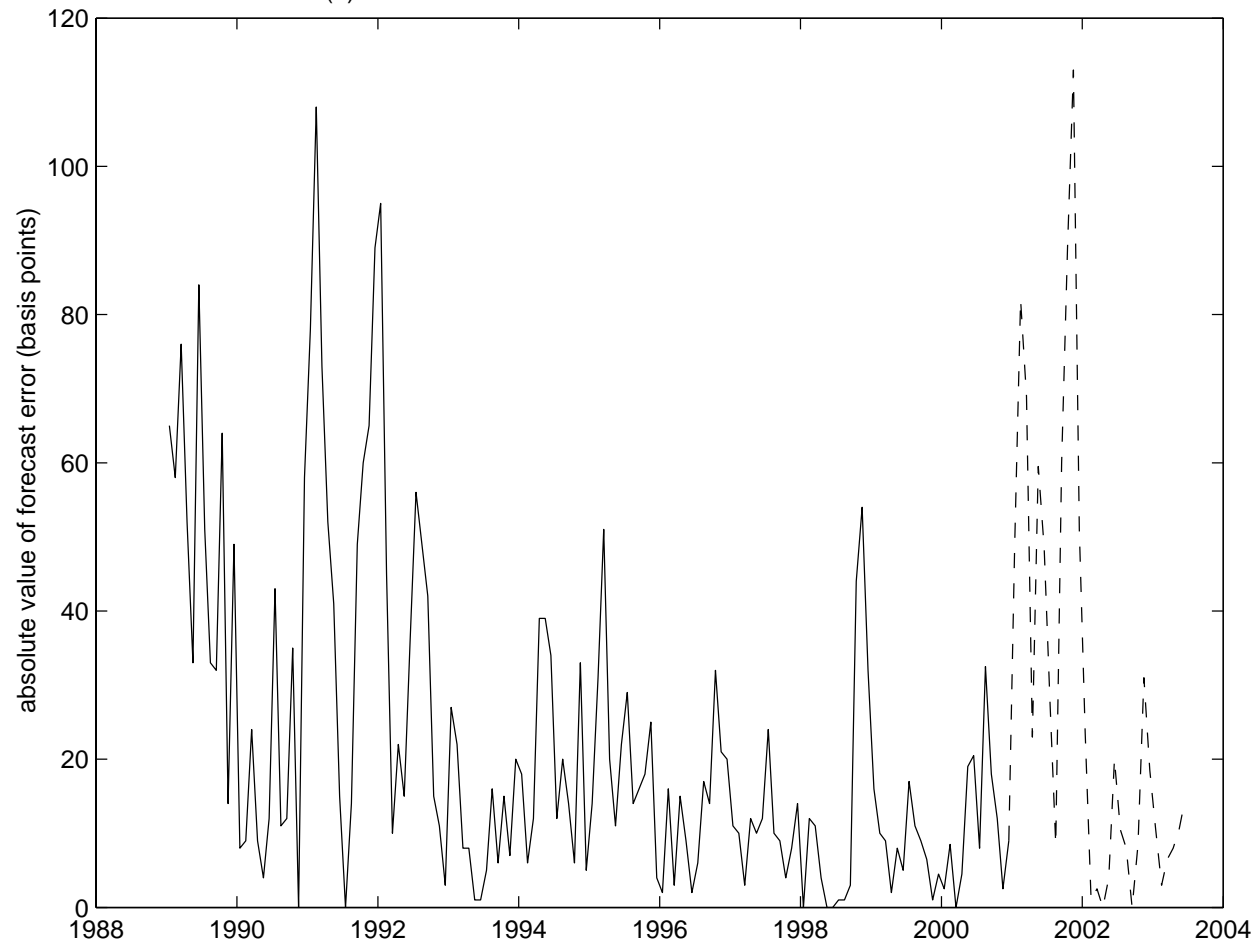

Solid line: 1988:11-2000:12 (top panel), 1989:1-2000:12 (bottom panel); dashed line: 2001:1-2003:6 (both panels). Data are monthly. Forecast error is realized average federal funds for given month minus federal funds futures forecast made 1 or 3 months previously. See text for details. 


\section{Table to Figure 1: Fed Funds Futures Market Forecast Errors} sample period constant time trend post-94 dummy

(a) 1-month-ahead fed funds futures forecast errors:

$\begin{array}{lllllll}\text { 1988:11-2000:12: } & 13.7 & {[9.41]} & -0.072 & {[-4.21]} & & \\ & 11.2 & {[10.02]} & & & -4.9 & {[-3.33]} \\ \text { 1988:11-2003:6: } & 12.5 & {[8.94]} & -0.049 & {[-3.61]} & & \\ & 11.2 & {[9.56]} & & & -4.7 & {[-3.23]}\end{array}$

(b) 3-month-ahead fed funds futures forecast errors:

$\begin{array}{llccccc}\text { 1989:1-2000:12: } & 42.3 & {[12.79]} & -0.267 & {[-6.96]} & & \\ & 33.3 & {[13.04]} & & & -19.4 & {[-5.76]} \\ 1989: 1-2003: 6: & 35.0 & {[9.81]} & -0.130 & {[-3.77]} & & \\ & 33.3 & {[11.52]} & & & -15.5 & {[-4.31]}\end{array}$

t-statistics reported in square brackets. Forecast errors are in basis points; time trend is in months. 


\section{Figure 2: Surprise Component of FOMC Announcements}

(a) Federal Funds Futures

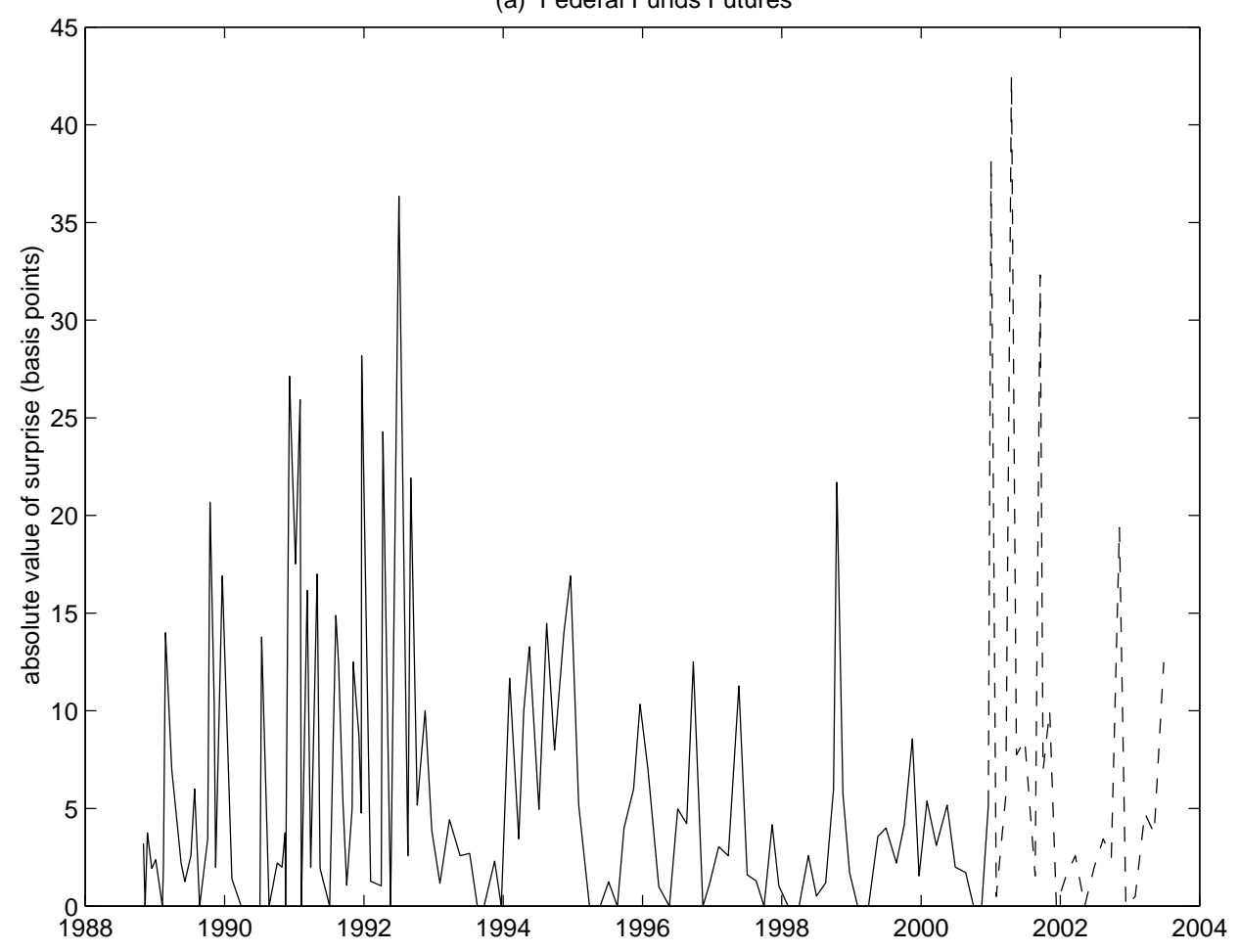

(b) 90-day Eurodollar Futures

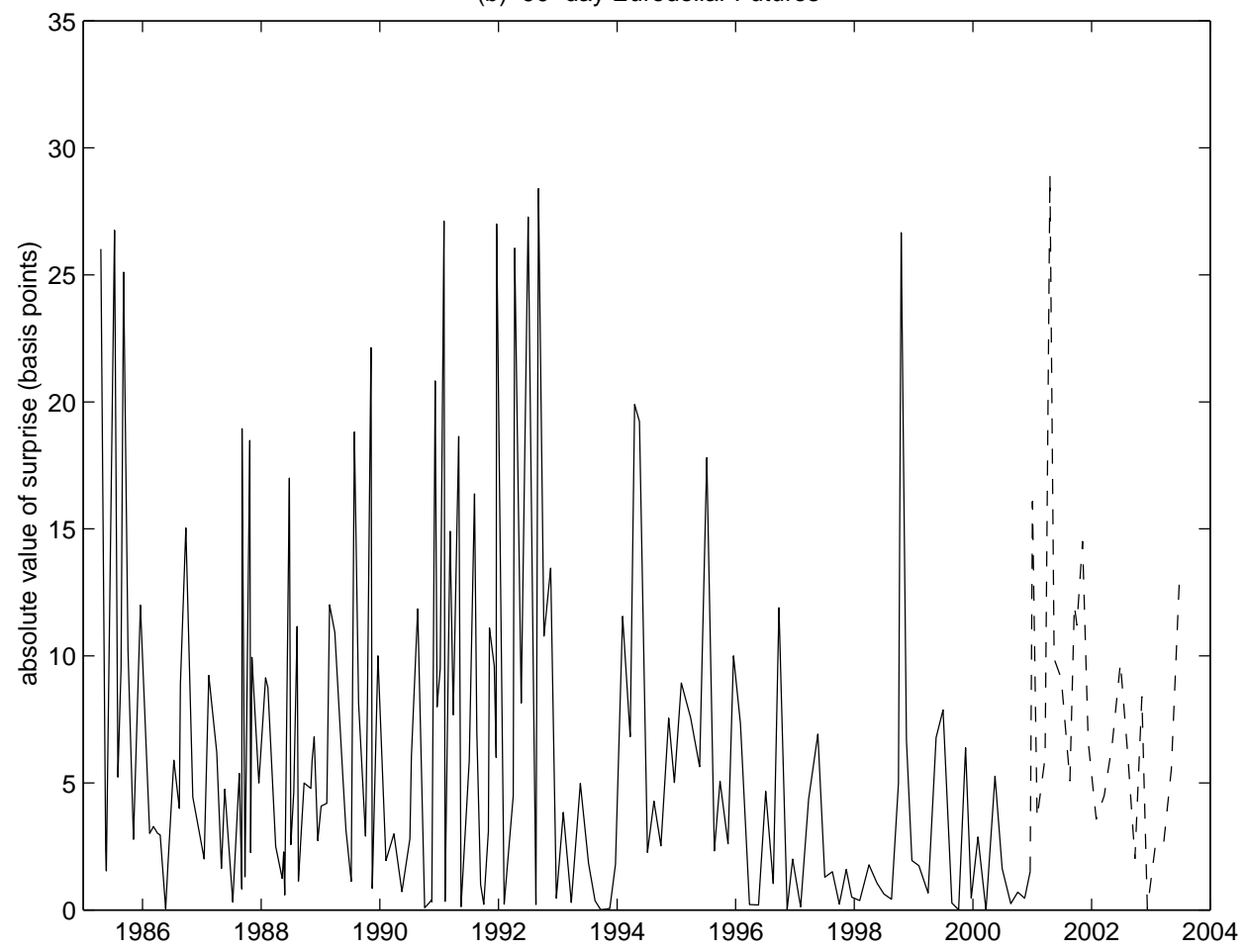

Solid line: 1988:10-2000:12 (top panel), 1985:4-2000:12 (bottom panel); dashed line: 2001:1-2003:6 (both panels). Surprise component is change in current-month or next-month fed funds futures contract scaled to account for number of days remaining in month (top panel) or change in 90-day eurodollar futures rate (bottom panel). See text for details. 
Table to Figure 2: Surprise Component of FOMC Announcements sample period constant time trend post-94 dummy

(a) federal funds futures:

$\begin{array}{lllllll}\text { 1988:11-2000:12: } & 8.0 & {[6.91]} & -0.032 & {[-2.15]} & & \\ & 7.1 & {[7.97]} & & & -2.5 & {[-1.92]} \\ \text { 1988:11-2003:6: } & 6.9 & {[5.58]} & -0.006 & {[-0.49]} & & \\ & 7.1 & {[6.91]} & & & -1.2 & {[-0.90]}\end{array}$

(b) 90-day eurodollar futures:

$\begin{array}{lllllll}\text { 1989:1-2000:12: } & 8.5 & {[8.85]} & -0.027 & {[-2.74]} & & \\ & 7.2 & {[11.19]} & & & -2.7 & {[-2.39]} \\ 1989: 1-2003: 6: & 7.7 & {[8.51]} & -0.012 & {[-1.50]} & & \\ & 7.2 & {[11.21]} & & & -1.6 & {[-1.64]}\end{array}$

t-statistics reported in square brackets. Surprises are in basis points; time trend is in months. 


\section{Figure 3: Market Uncertainty, Eurodollar Options}

(a) Implied Volatility in basis points (assuming lognormal distribution)

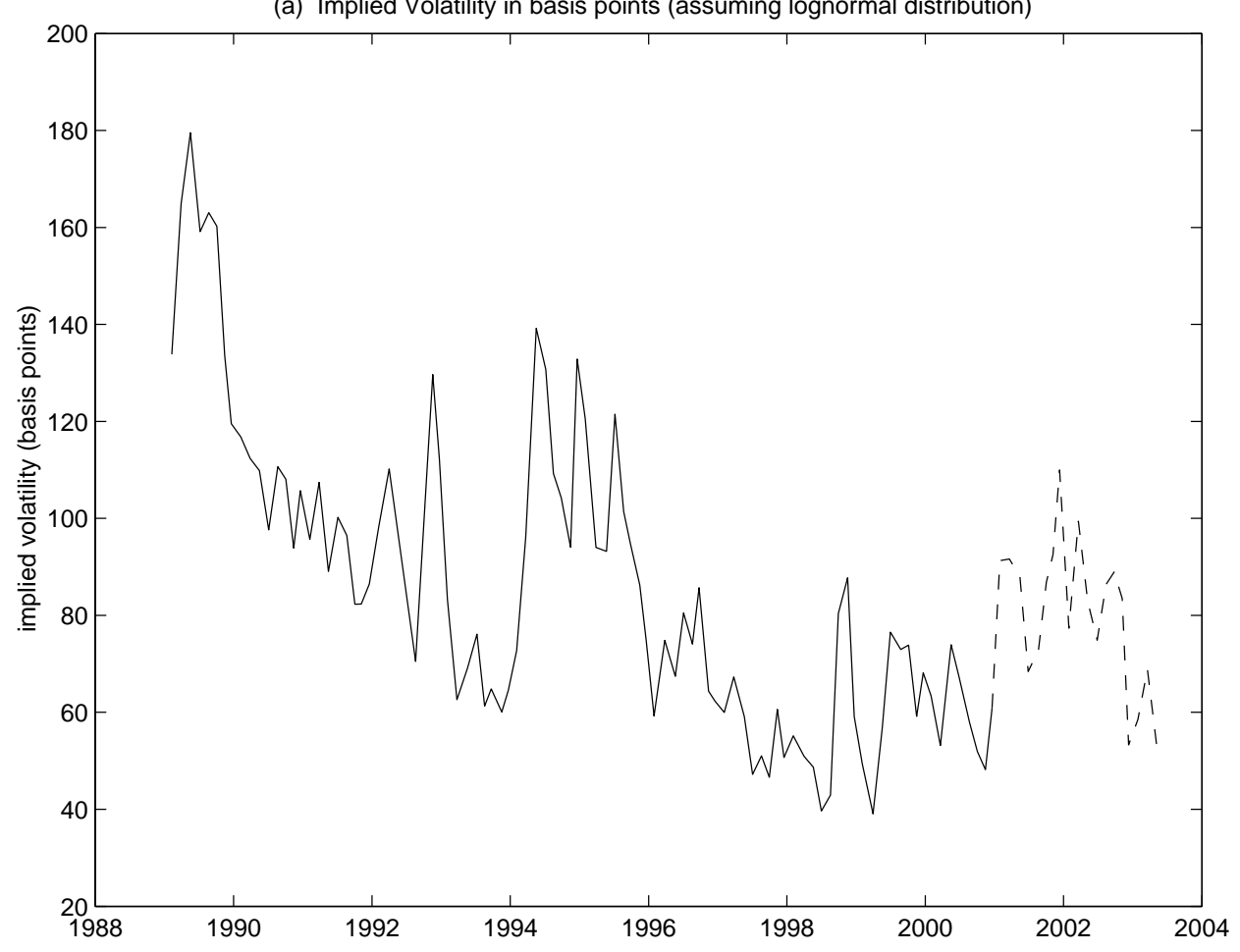

(b) 75-25 Percentile Difference of General pdf (using multiple strikes)

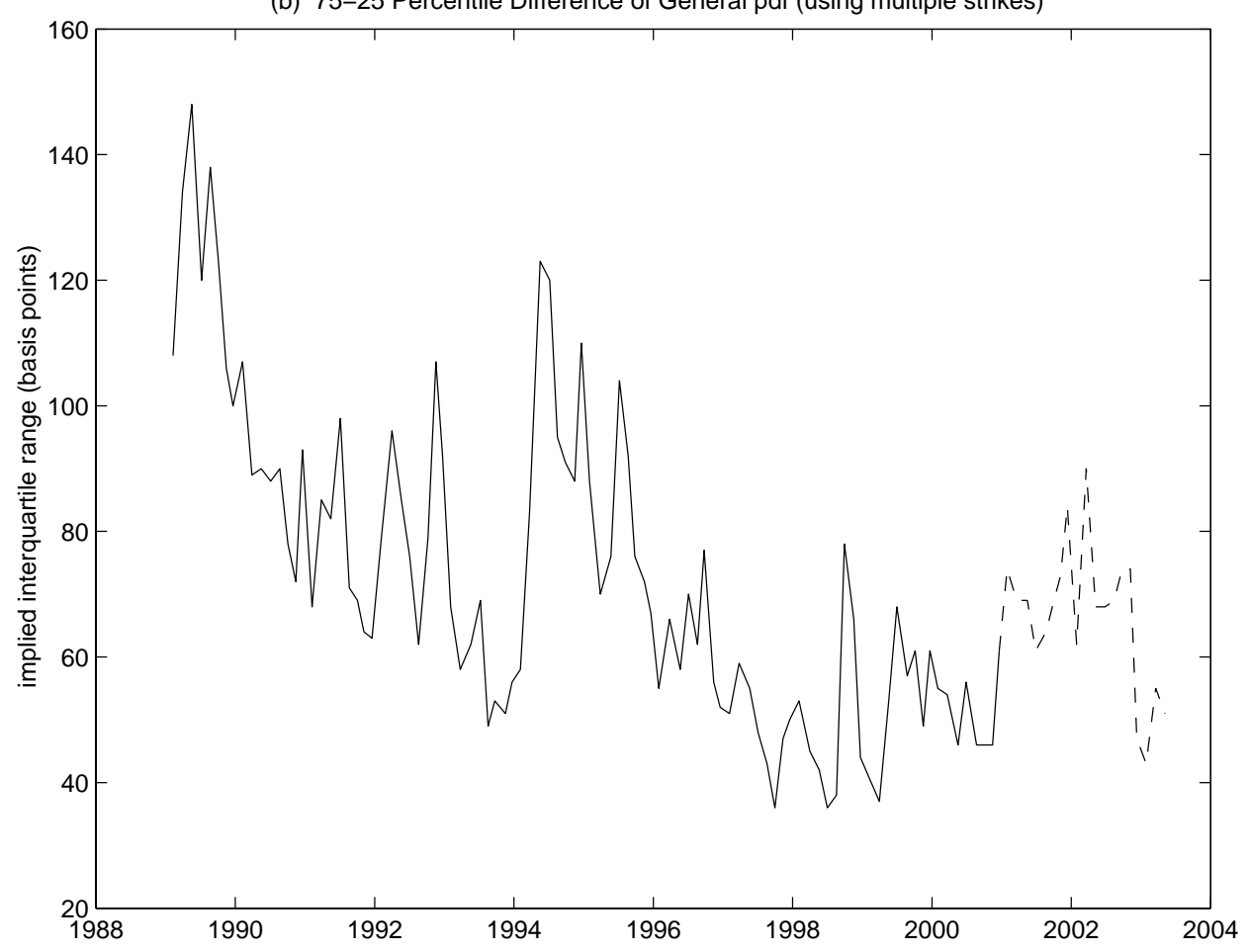

Solid lines: 1989:1-2000:12; dashed lines: 2001:1-2003:6. Data are sampled on days before scheduled FOMC meetings. Options are on 90-day eurodollar deposits with expiration six months ahead. "Implied volatility" (top panel) is derived from at-the-money option assuming a lognormal distribution, and is expressed in basis points rather than logs. The bottom panel uses all available options with the same expiration to estimate a more general probability distribution, and plots the difference between the 75 th and 25 th percentiles. See text for details. 


\section{Table to Figure 3: Market Uncertainty, Eurodollar Options} sample period constant time trend post-94 dummy

(a) implied volatility in basis points (lognormal distribution):

$\begin{array}{lllllll}\text { 1989:1-2000:12: } & 125.9 & {[29.14]} & -0.547 & {[-10.60]} & & \\ & 103.8 & {[24.14]} & & & -30.4 & {[-5.39]} \\ 1989: 1-2003: 6: & 115.6 & {[26.54]} & -0.351 & {[-8.05]} & & \\ & 103.8 & {[25.58]} & & & -28.6 & {[-5.69]}\end{array}$

(b) 75-25 percentile difference of general pdf:

$\begin{array}{rrrrrrr}\text { 1989:1-2000:12: } & 103.2 & {[28.44]} & -0.422 & {[-9.73]} & & \\ & 85.7 & {[24.25]} & & & -22.5 & {[-4.86]} \\ \text { 1989:1-2003:6: } & 95.6 & {[27.13]} & -0.278 & {[-7.88]} & & \\ & 85.7 & {[25.87]} & & & -21.6 & {[-5.28]}\end{array}$

t-statistics reported in square brackets. Left-hand side variables are in basis points; time trend is in months. 
Figure 4: Cross-Sectional Dispersion of Private Sector Forecasts

(a) One-quarter-ahead Forecast of 3-month Treasury Bill Rate

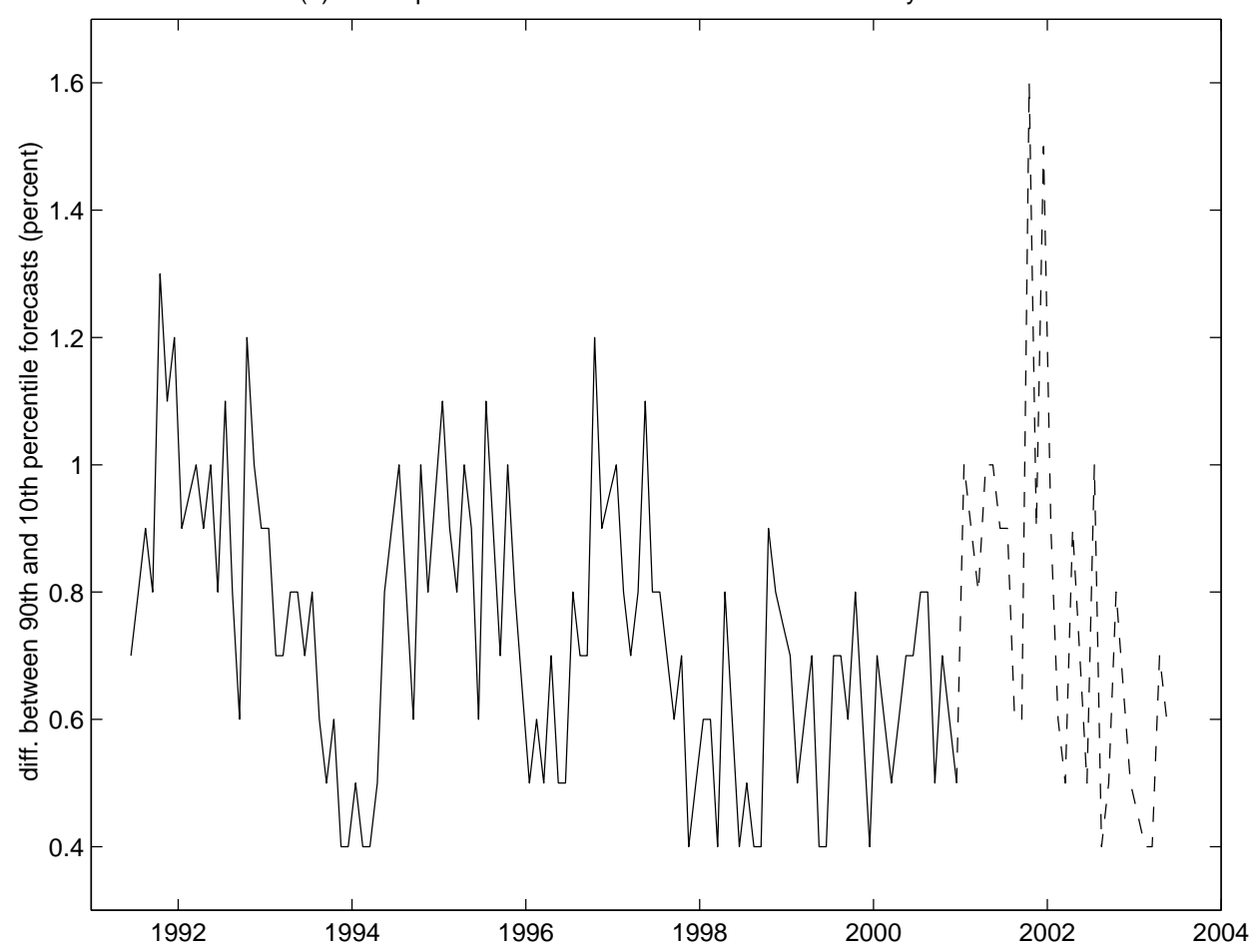

(b) Four-quarter-ahead Forecast of 3-month Treasury Bill Rate

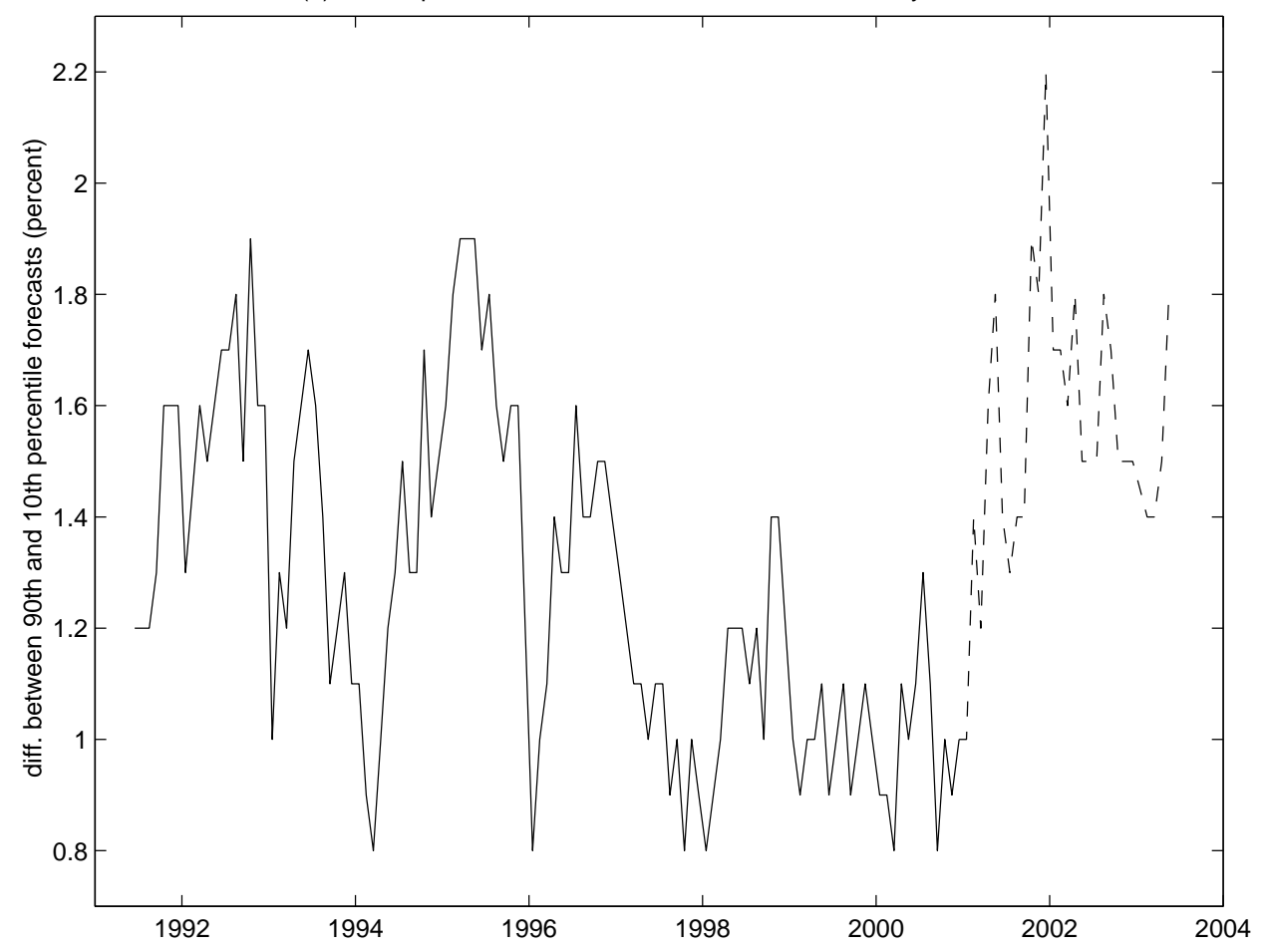

Solid lines: 1991:6-2000:12; dashed lines: 2001:1-2003:6. Data are monthly. Cross-sectional dispersion is difference between 90th and 10th percentile Blue Chip forecast of Treasury bill rate. See text for details. 
Table to Figure 4: Cross-sectional Dispersion of Private Sector Forecasts sample period constant time trend post-94 dummy

(a) 90-10 percentile range in 1-quarter-ahead forecast of 3-mo. T-bill rate:

$\begin{array}{lllllll}\text { 1991:6-2000:12: } & 0.890 & {[24.59]} & -0.0027 & {[-4.97]} & & \\ & 0.834 & {[22.80]} & & & -0.137 & {[-3.21]} \\ \text { 1991:6-2003:6: } & 0.835 & {[22.15]} & -0.0013 & {[-2.91]} & & \\ & 0.834 & {[20.52]} & & & -0.120 & {[-2.61]}\end{array}$

(b) 90-10 percentile range in 4-quarter-ahead forecast of 3-mo. T-bill rate:

$$
\begin{array}{lllllll}
\text { 1991:6-2000:12: } & 1.566 & {[34.61]} & -0.0051 & {[-7.59]} & & \\
& 1.450 & {[29.45]} & & & -0.250 & {[-4.34]} \\
\text { 1991:6-2003:6: } & 1.371 & {[26.66]} & -0.0006 & {[-1.00]} & & \\
& 1.450 & {[26.82]} & & & -0.158 & {[-2.58]}
\end{array}
$$

t-statistics reported in square brackets. Left-hand side variables are in percent; time trend is in months. 
Figure 5: Federal Funds Rate Target and 90-Day "Momentum"

(a) Federal Funds Rate Target

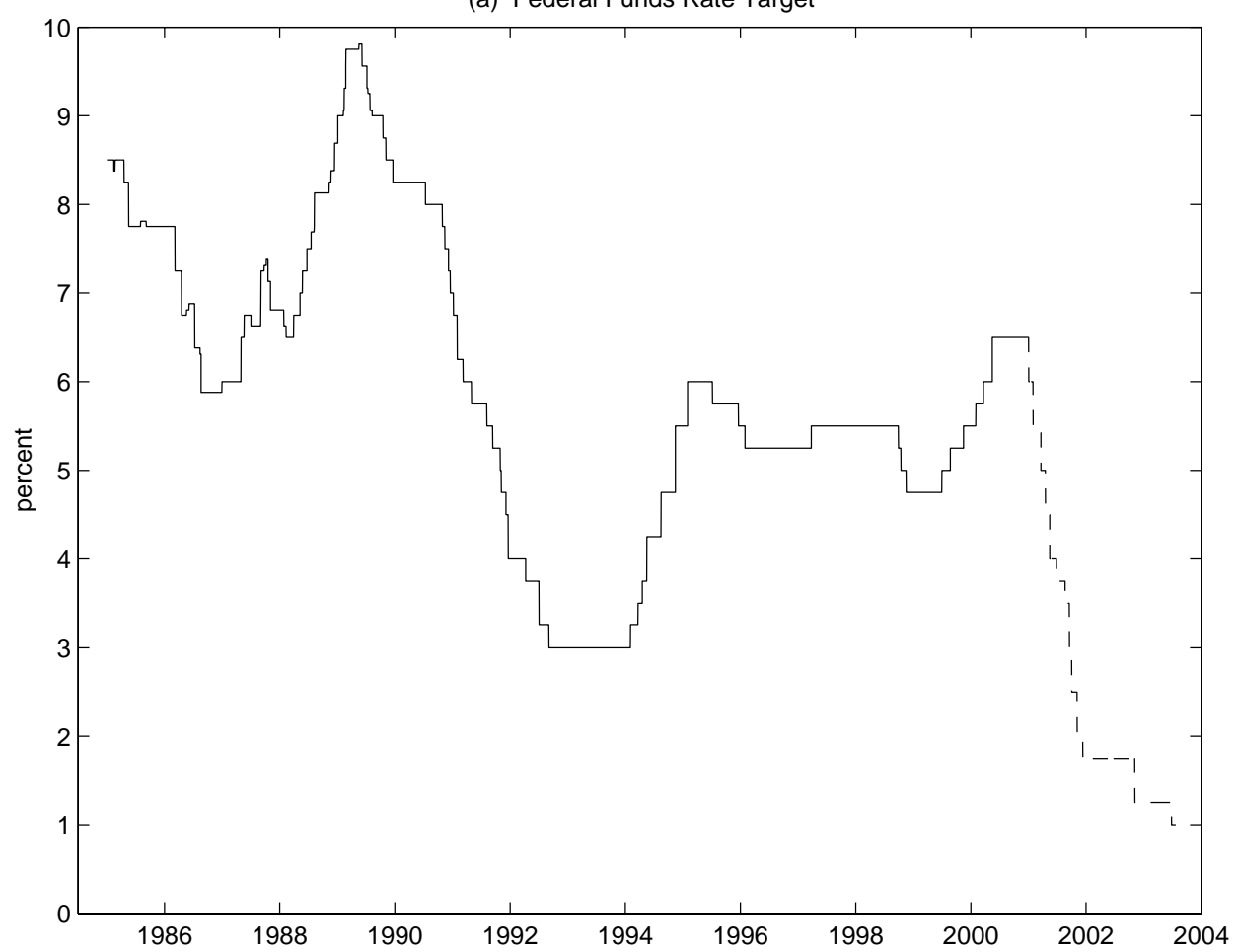

(b) Federal Funds Rate, change from 90 Days Previous (absolute value)

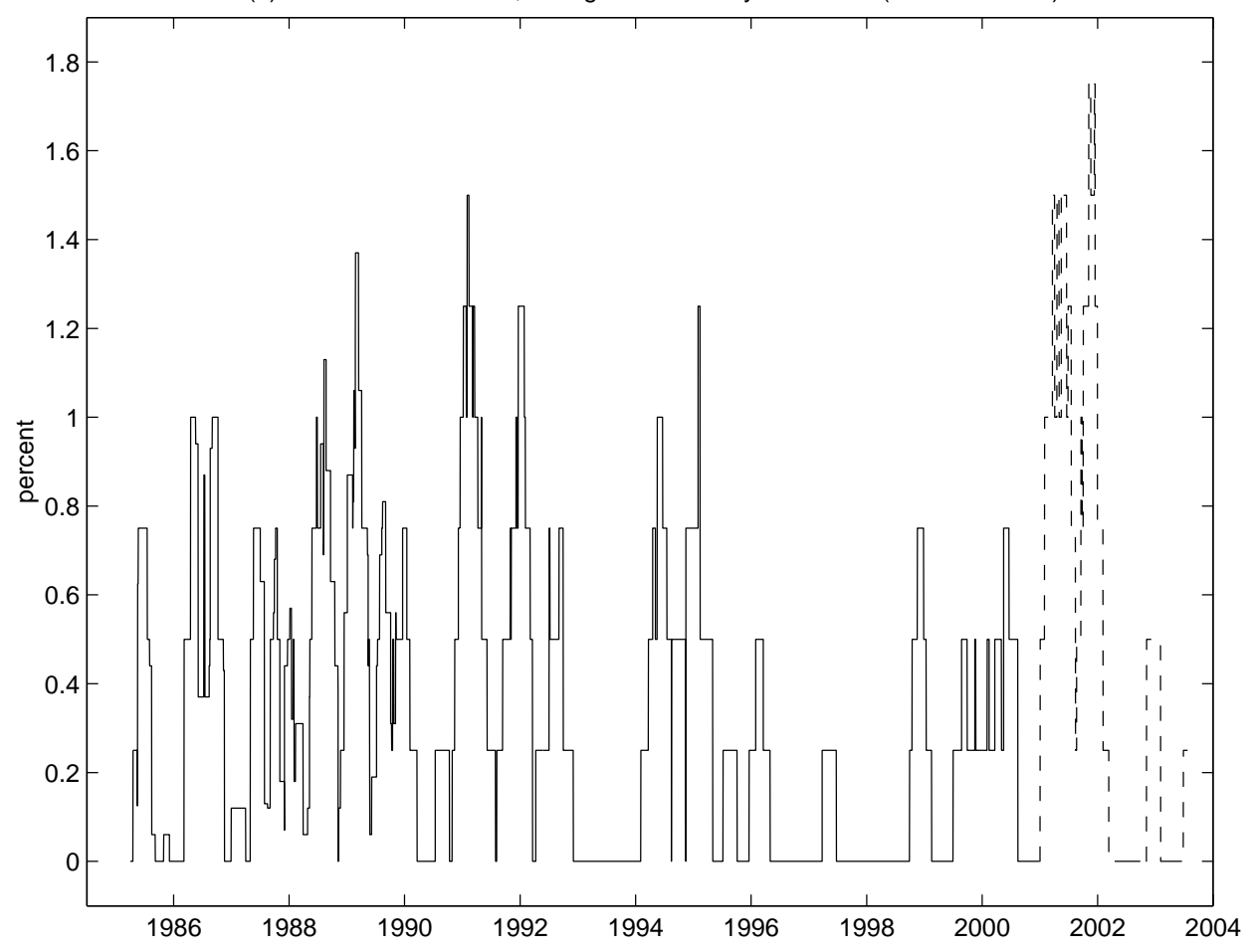

Solid lines: 1985:1-2000:12; dashed lines: 2001:1-2003:6. Data are daily. "Momentum" is absolute value of difference between current federal funds rate target and funds rate target from 90 days previous. 
Figure 6: Cross-Sectional Dispersion of Private Sector Macro Forecasts

(a) One-quarter-ahead Forecast of Real GDP Growth

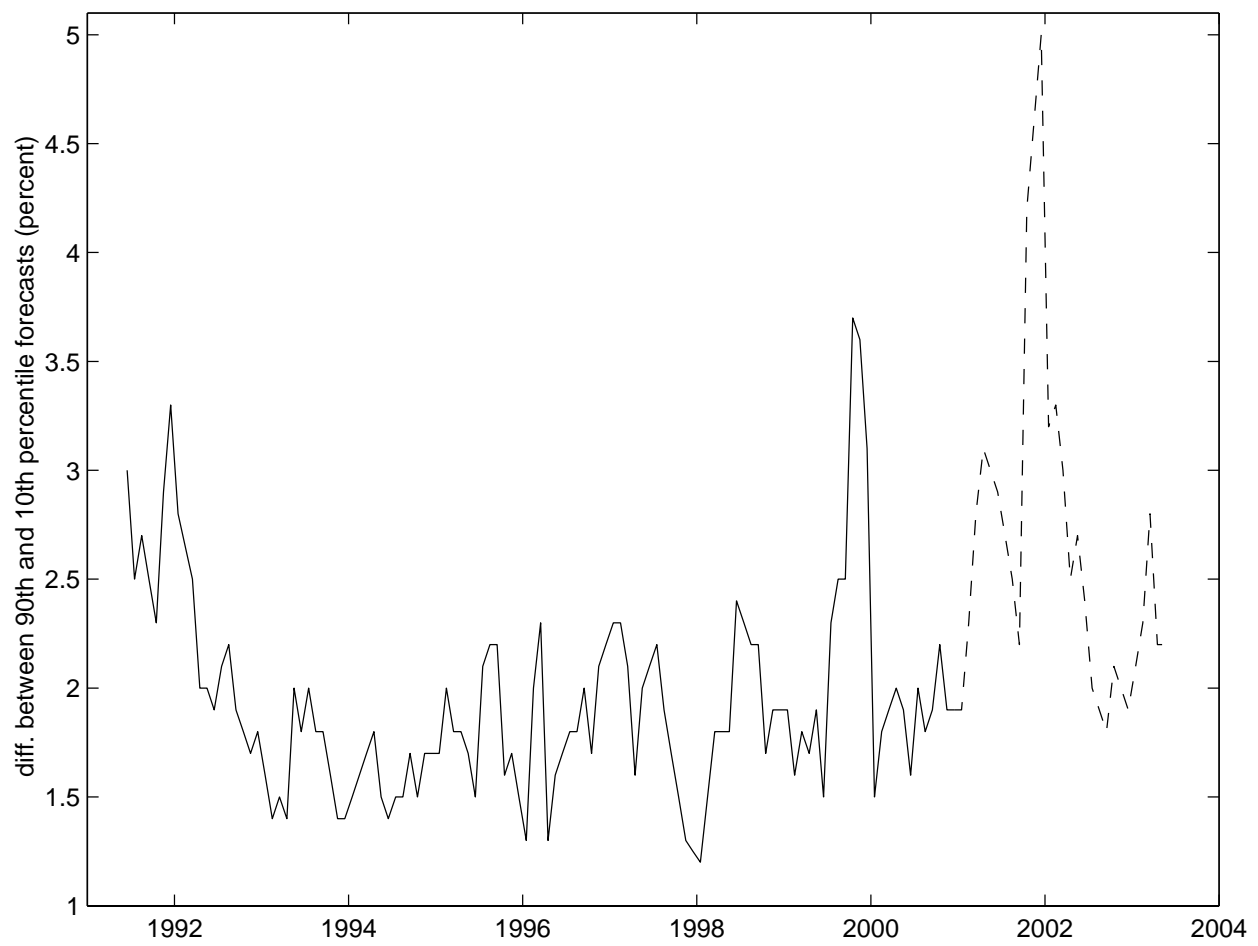

(b) One-quarter-ahead Forecast of GDP Deflator Inflation

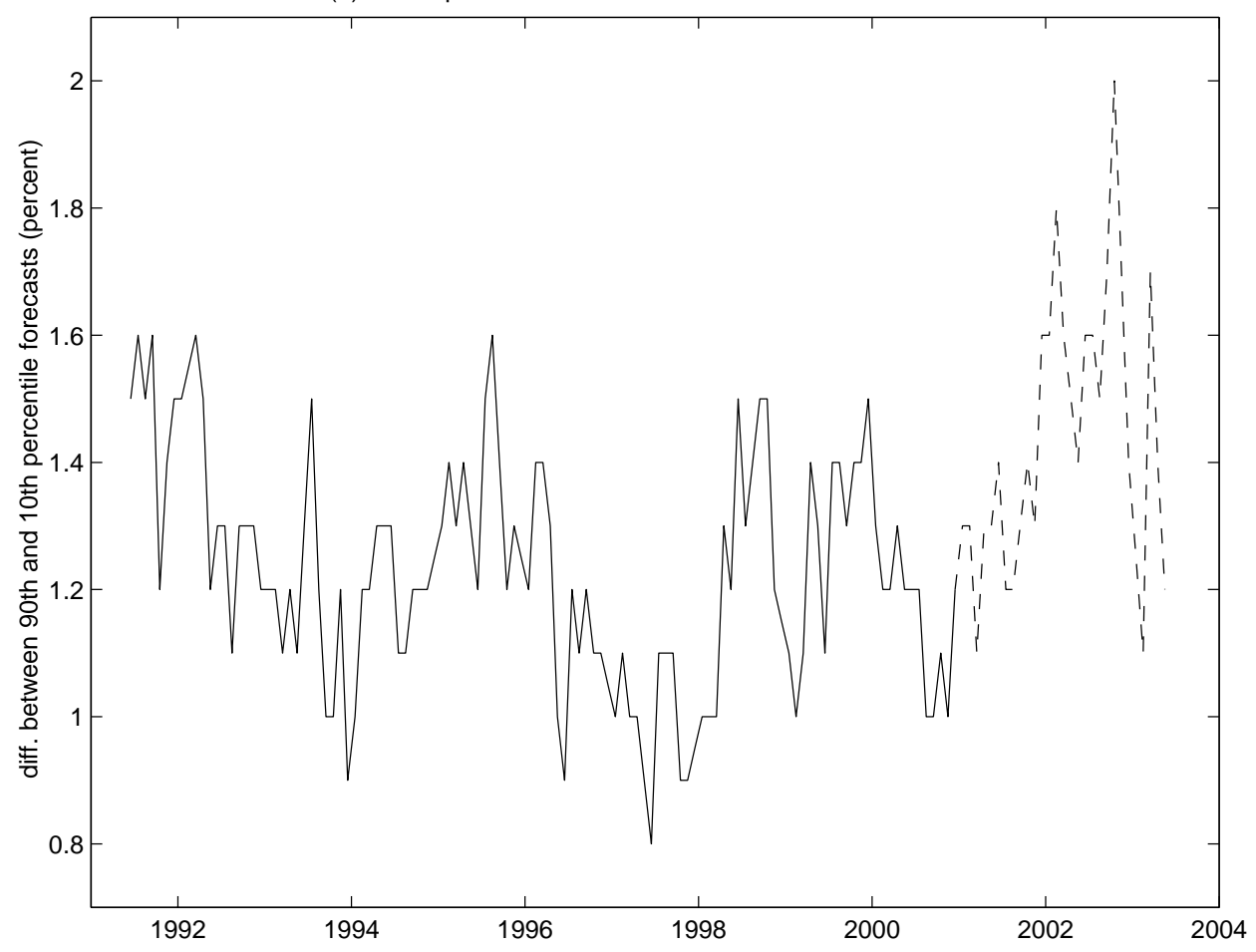

Solid lines: 1991:6-2000:12; dashed lines: 2001:1-2003:6. Data are monthly. Cross-sectional dispersion is difference between 90th and 10th percentile Blue Chip forecast of real GDP growth (top panel) or GDP Deflator inflation (bottom panel). See text for details. 
Table 5: Federal Funds Rate Momentum and Economic Uncertainty as Explanators for Variation in Market Forecast ACCURACy

$\begin{array}{cccc} & \text { federal } & \text { GDP } & \text { inflation } \\ \text { funds rate } & \text { forecast } & \text { forecast } \\ \text { time trend } & \text { momentum } & \text { dispersion } & \text { dispersion }\end{array}$

(a) Federal Funds Futures Forecast Errors

$$
\begin{array}{lllrlrrrr}
\text { 1-month-ahead: } & -.043 & {[-3.30]} & 8.32 & {[4.93]} & & & & \\
& -.047 & {[-2.53]} & & & 1.57 & {[1.14]} & 0.90 & {[0.23]} \\
& -.042 & {[-2.36]} & 7.38 & {[3.60]} & -0.67 & {[-0.46]} & 1.70 & {[0.44]} \\
\text { 3-month-ahead: } & -.094 & {[-4.01]} & 43.22 & {[14.26]} & & & & \\
& -.131 & {[-3.14]} & & & 18.87 & {[6.08]} & -12.02 & {[-1.33]} \\
& -.106 & {[-3.49]} & 38.43 & {[10.96]} & 7.20 & {[2.89]} & -7.83 & {[-1.20]}
\end{array}
$$

(b) Surprise Component of FOMC Announcements

$\begin{array}{crrrrrrrr}\text { fed funds futures: } & .001 & {[0.05]} & 7.87 & {[5.55]} & & & & \\ & -.024 & {[-1.19]} & & & 1.10 & {[0.73]} & 4.86 & {[0.93]} \\ & -.019 & {[-1.04]} & 10.12 & {[4.94]} & -2.99 & {[-1.89]} & 6.92 & {[1.48]} \\ \text { eurodollar futures: } & -.000 & {[-0.04]} & 6.46 & {[6.09]} & & & & \\ & -.034 & {[-2.08]} & & & 1.04 & {[0.87]} & 9.60 & {[2.31]} \\ & -.029 & {[-2.06]} & 8.90 & {[5.59]} & -2.55 & {[-2.08]} & 11.41 & {[3.13]}\end{array}$

(c) Uncertainty from Eurodollar Options

$$
\begin{array}{lllllrrrr}
\text { implied vol (bp): } & -.346 & {[-9.06]} & 26.33 & {[5.93]} & & & & \\
& -.232 & {[-4.62]} & & & 1.34 & {[0.38]} & 51.06 & {[4.30]} \\
& -.219 & {[-5.21]} & 27.33 & {[6.06]} & -9.31 & {[-2.74]} & 57.96 & {[5.79]} \\
75-25 \text { pctile diff: } & -.274 & {[-8.37]} & 16.96 & {[4.45]} & & & & \\
& -.186 & {[-4.40]} & & & -1.27 & {[-0.43]} & 43.85 & {[4.38]} \\
& -.178 & {[-4.70]} & 19.20 & {[4.74]} & -8.75 & {[-2.86]} & 48.69 & {[5.42]}
\end{array}
$$

(d) Cross-sectional Dispersion of Forecasters

$$
\begin{array}{rrrrrrrrr}
\text { 1-quarter-ahead: } & -.0014 & {[-3.37]} & 0.283 & {[5.99]} & & & & \\
& -.0020 & {[-4.50]} & & & 0.171 & {[5.10]} & -0.009 & {[-0.09]} \\
& -.0019 & {[-4.38]} & 0.197 & {[3.75]} & 0.109 & {[3.01]} & 0.005 & {[0.06]} \\
\text { 1-year-ahead: } & -.0009 & {[-1.45]} & 0.277 & {[4.04]} & & & & \\
& -.0016 & {[-2.69]} & & & 0.115 & {[2.55]} & 0.524 & {[4.01]} \\
& -.0015 & {[-2.52]} & 0.174 & {[2.41]} & 0.059 & {[1.19]} & 0.536 & {[4.18]}
\end{array}
$$

t-statistics reported in square brackets. Left-hand side variables are the same as in Figures 1 through 4. 


\section{Figure 7: Private Sector Forecast Errors, Macro Variables}

(a) One-quarter-ahead Forecast Error for Real GDP Growth

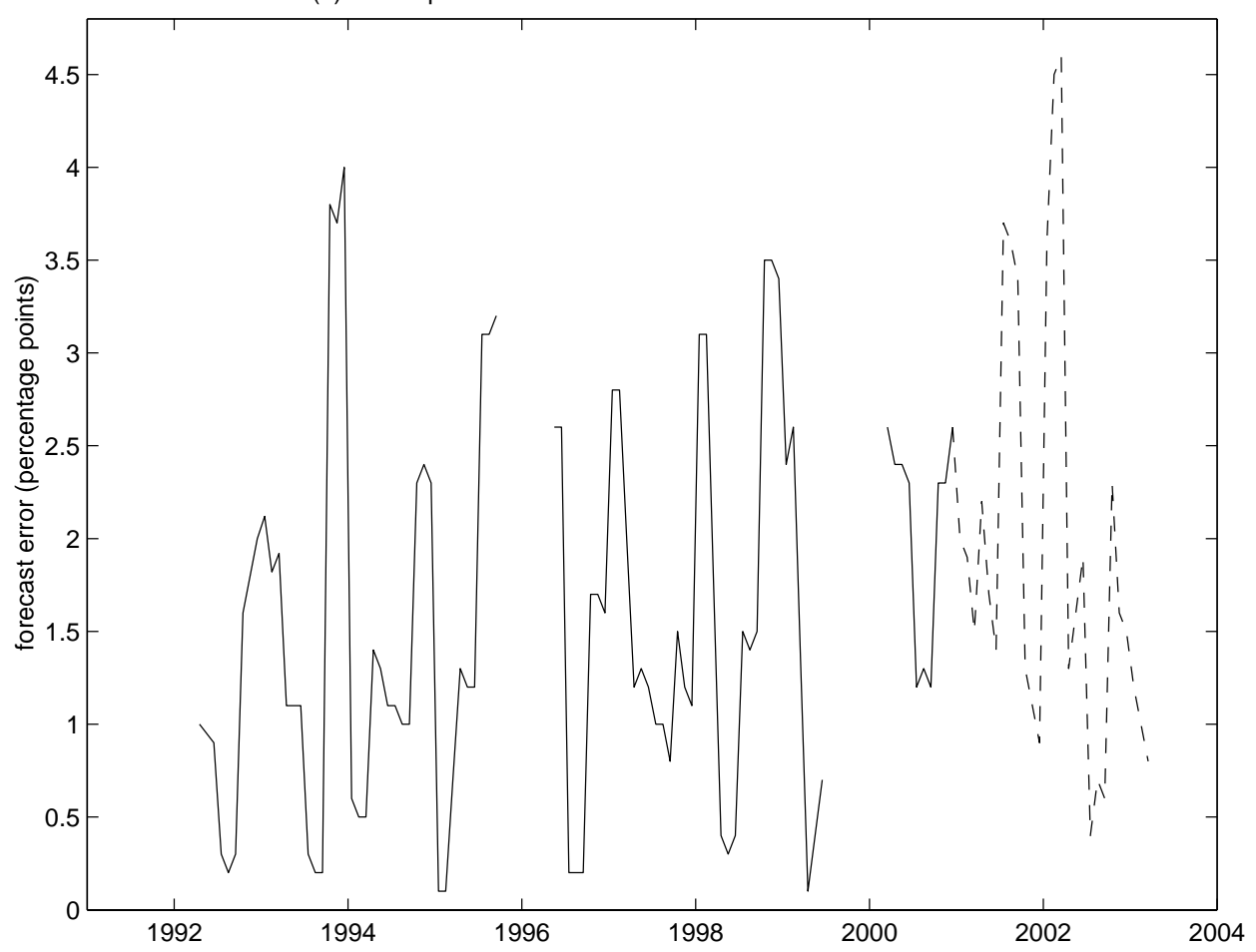

(b) One-quarter-ahead Forecast Error for GDP Deflator Inflation

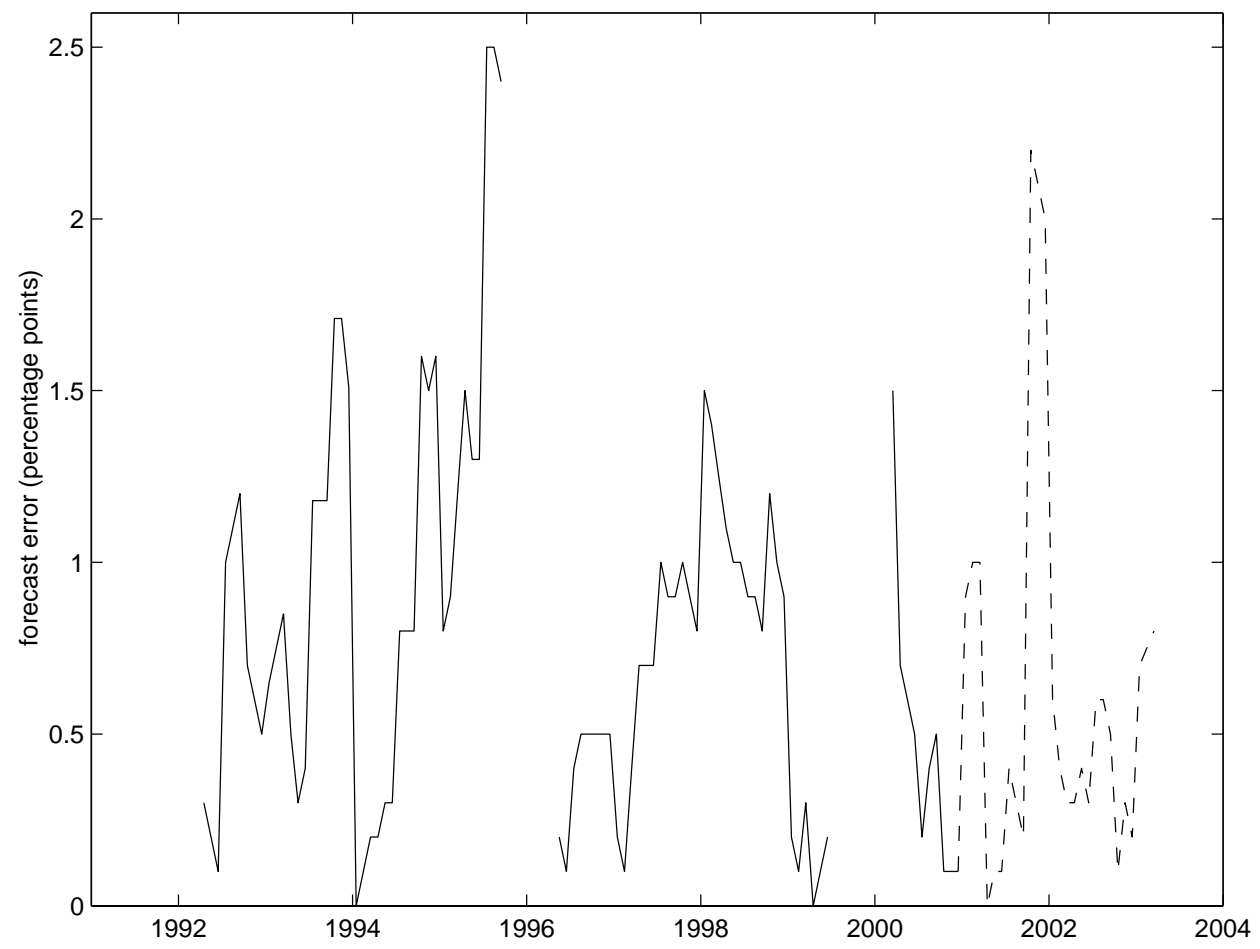

Solid lines: 1991:6-2000:12; dashed lines: 2001:1-2003:6. Data are monthly. Forecast error is realized value minus median Blue Chip consensus forecast of real GDP growth (top panel) or GDP Deflator inflation (bottom panel). Forecast errors that would be affected by NIPA benchmark revisions in Dec. 1991, Jan. 1996, and Oct. 1999 are excluded. See text for details. 
Table 6: Tests for Downward Trend in Macroeconomic Forecast Dispersion AND ForECAST ERRORS

constant time trend

(a) Cross-Sectional Dispersion of Forecasts

Real GDP Growth:

\begin{tabular}{|c|}
\hline arter-ahead: \\
\hline 1-year-ahead: \\
\hline
\end{tabular}

GDP Deflator Inflation:

\begin{tabular}{|c|c|c|c|}
\hline & 1.314 & [39.9] & -.0015 \\
\hline 1-year-ah & 1.472 & [37.0] & -.0019 \\
\hline
\end{tabular}

Three-Month Treasury Bill Rate:

\begin{tabular}{|c|c|c|}
\hline quarter-ahead: & 0.890 & {$[24.6]$} \\
\hline 1-year-ah & 1.566 & {$[34.6]$} \\
\hline
\end{tabular}

(b) Forecast Errors

Real GDP Growth:

\begin{tabular}{|c|c|c|}
\hline -quarter-ahead: & 1.173 & {$[5.2$} \\
\hline 1-year-ahead: & 1.397 & {$[4.0$} \\
\hline
\end{tabular}

GDP Deflator Inflation:

\begin{tabular}{|c|c|c|}
\hline arter-ahead: & 0.959 & {$[7.7$} \\
\hline 1-year-ahead: & 1.018 & {$[5.4$} \\
\hline
\end{tabular}

Three-Month Treasury Bill Rate:

$$
\begin{aligned}
& \text { 1-quarter-ahead: } \quad \begin{array}{lllll}
0.555 & {[11.1]} & -.0036 & {[-4.68]}
\end{array} \\
& \text { 1-year-ahead: } \quad 1.585 \quad[11.5] \quad-.0110 \quad[-5.43]
\end{aligned}
$$

t-statistics reported in square brackets. Sample period: 1991:6-2000:12; data are monthly. Cross-sectional dispersion of forecasts is 90-10 percentile difference in Blue Chip survey of forecasters. Forecast errors are the ex post realized value of the series minus the 1-quarter-ahead (or 1-year-ahead) median Blue Chip consensus forecast made the previous quarter (or previous year). 
Figure 8: Change in Market Uncertainty from Day Before to Day After FOMC ANNOUNCEMENT, FROM EURODOLLAR OPTIONS

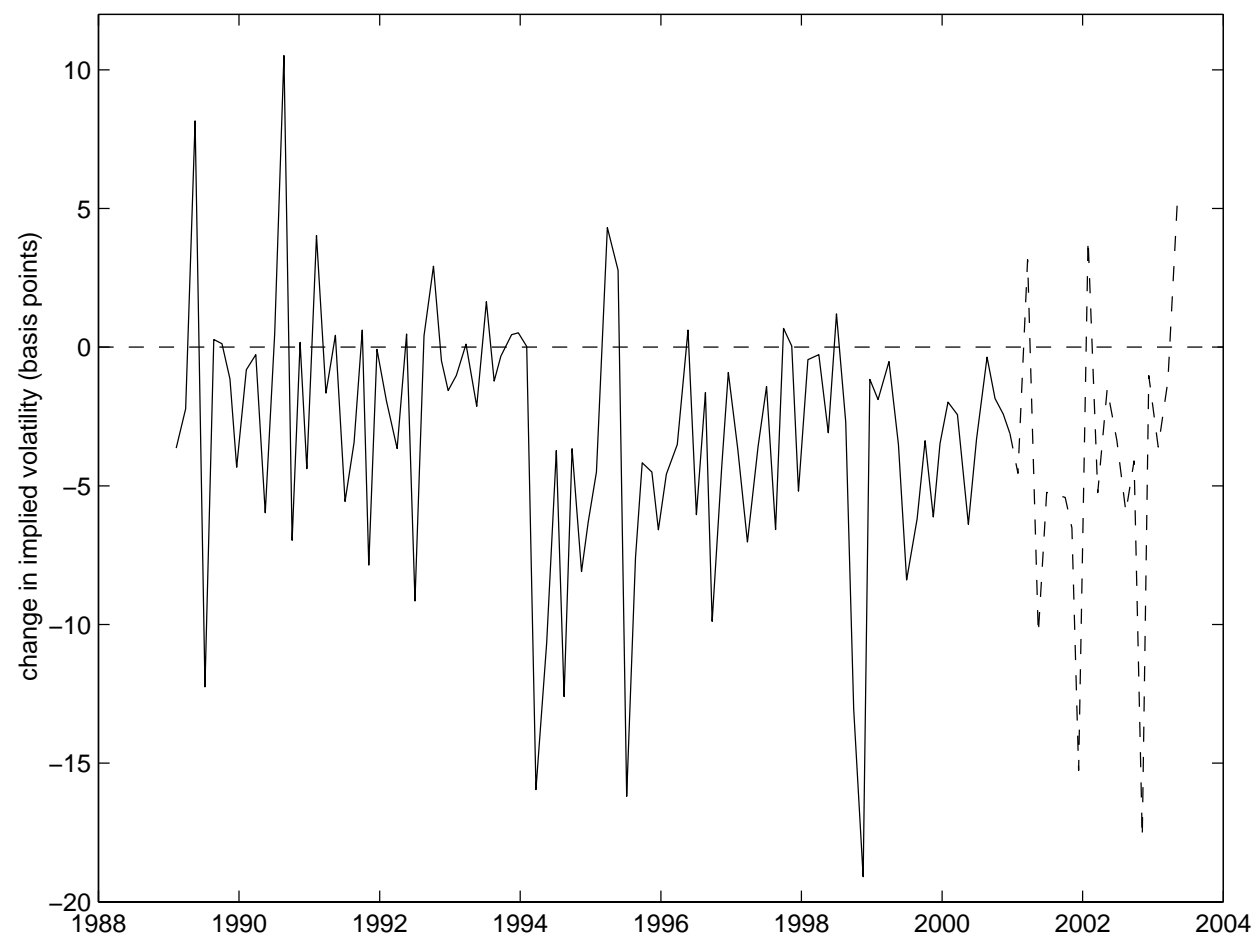

Solid lines: 1989:1-2000:12; dashed lines: 2001:1-2003:6. Data are sampled at regularly scheduled FOMC meetings. Change in market uncertainty is change in implied volatility (in basis point terms) from Figure 3. See text for details.

TABLE TO FIGURE 8

\begin{tabular}{|c|c|c|}
\hline sample period & constant & post-94 dummy \\
\hline 1989:1-2003:6 & {$[-1.83]$} & -3.166 \\
\hline
\end{tabular}

t-statistics reported in square brackets. Left-hand side variable is change in market uncertainty from Figure 8 . 